\title{
Physico-chemical and elemental investigation of aqueous leaching of high sulfur coal and mine overburden from Ledo coalfield of Northeast India
}

\author{
Madhulika Dutta $^{1,2,3} \cdot$ Puja Khare $^{4} \cdot$ Sanchita Chakravarty $^{5} \cdot$ Durlov Saikia $^{2} \cdot$ \\ Binoy K. Saikia ${ }^{1}$ (D)
}

Received: 2 January 2018/Revised: 12 June 2018/Accepted: 25 June 2018/Published online: 5 July 2018

(C) The Author(s) 2018

\begin{abstract}
Acid mine drainage (AMD) is one of the major problems in high sulfur coal mining areas generating acidic water. The acidic mine water generated contain hazardous elements in varying concentrations. The Northeastern Indian coalfield produces considerable amounts of AMD. The AMD and metal leaching from coal and mine over burden (OB) are the two important naturally occurring processes. In order to know the AMD potential, the aqueous leaching experiment of a few coal and OB samples from the Ledo colliery of the Northeastern coalfield, Mergherita (India), at different time periods $(1,3,5$, and $8 \mathrm{~h})$ and at different temperatures $\left(25,45,65\right.$, and $\left.90^{\circ} \mathrm{C}\right)$ were performed in the laboratory. The physicochemical analysis of the aqueous leachates shows the $\mathrm{pH}$, electrical conductivity (EC), and total dissolved solid (TDS) in the range of 1.62-3.52, 106-2006 $\mu \mathrm{s} / \mathrm{cm}$, and 106-1003 ppm for the raw coal samples respectively. The OB samples produced $\mathrm{pH}, \mathrm{EC}$, and TDS in the range of 3.68-6.92, 48.6-480 $\mu \mathrm{s} / \mathrm{cm}$, and 69.5-240 ppm respectively. From the study, it was revealed that the concentrations of major ( $\mathrm{Si}, \mathrm{Al}, \mathrm{K}, \mathrm{Na}, \mathrm{Fe}, \mathrm{Ca}, \mathrm{Mg}$ ), minor (Mn) and trace/hazardous elements (As, $\mathrm{Ba}, \mathrm{Cd}, \mathrm{Co}, \mathrm{Cr}, \mathrm{Cu}, \mathrm{Hg}, \mathrm{Ni}, \mathrm{Pb}, \mathrm{Se}, \mathrm{Zn}$ ) considerably change with leaching time as well as with leaching temperature. Out of these elements $\mathrm{As}, \mathrm{Cd}, \mathrm{Hg}, \mathrm{Pb}, \mathrm{Cr}$, and $\mathrm{Se}$ are of greater environmental importance. Alteration of the physico-chemical structure of the coal and $\mathrm{OB}$ samples resulting from leaching was also studied by field emission scanning electron microscope- energy-dispersive X-ray spectroscopy method. The release of the potentially hazardous elements from the raw coal and $\mathrm{OB}$ during leaching time periods to the leachates was detected by inductively coupled plasma-atomic emission spectroscopy and ion-chromatographic analyses. The major minerals found in coal and $\mathrm{OB}$ are quartz $\left(\mathrm{SiO}_{2}\right), \mathrm{pyrite}\left(\mathrm{FeS} \mathrm{S}_{2}\right)$, hematite, marcasite, and kaolinite. The association of different functional groups in minerals and their mode of association were studied by Fourier-transform infrared spectroscopy and X-ray diffraction analytical techniques. The present laboratory study will be useful in relating the characteristics of aqueous leaching from coal and mine OB with the natural weathering condition at the coal mine area.
\end{abstract}

Keywords AMD · High sulfur coal · Coal mine overburden · Aqueous leaching · Elements in coal and OB · Coal quality assessment

Electronic supplementary material The online version of this article (https://doi.org/10.1007/s40789-018-0210-9) contains supplementary material, which is available to authorized users.

Binoy K. Saikia

bksaikia@neist.res.in; bksaikia@gmail.com

1 Polymer Petroleum and Coal Chemistry Group, Materials Sciences and Technology Division, CSIR-North East Institute of Science and Technology, Jorhat 785006, India

2 School of Applied Sciences, Department of Chemistry, University of Science and Technology,

Ribhoi 793101, Meghalaya, India
3 Department of Chemistry, CNB College, Bokakhat 785612, India

4 Agrotechnology Division, CSIR- Central Institute of Medicinal and Aromatic Plants, Lucknow 226015, India

5 Analytical Chemistry Division, CSIR- National Metallurgical Laboratory, Jamshedpur 831007, India 


\section{Introduction}

Coal is a heterogeneous mixture of different organic and inorganic materials. Majority of inorganic materials are occurred in mineral forms. The minerals present in coal consist of several metals and nonmetals especially $\mathrm{Si}, \mathrm{S}$, $\mathrm{Ca}, \mathrm{Mg}, \mathrm{Fe}, \mathrm{Al}$ etc. (Tomeczec and Palugniok 2002; Mukherjee and Borthakur 2003). The common minerals found in coal and associated mine rejects (OB) are quartz $\left(\mathrm{SiO}_{2}\right)$, pyrite $\left(\mathrm{FeS}_{2}\right)$, hematite, marcasite, and kaolinite. Coal is composed of different elements, metals, and nonmetals as a long biological and physical alteration process taken place during the formation of the coal (Swine 1990; Singh and Singh 1995). Before mining these elements are in an immobile state, but during and after mining they have a tendency to disperse into the surrounding areas (Equeenuddin 2015).

Most of these elements are found in trace amount which are toxic in nature beyond their threshold limit. Trace elements are those whose concentrations are lower than $0.1 \%$ in the coal (Swaine 2000; Singh et al. 2012a). The study of these trace elements is very important due to their complex changes, inability to decompose in natural processes like weathering and high toxicity to the environment followed by their release and dispersal to the atmosphere, soil and water through the pathways of leaching and weathering (Zhou et al. 2014; Querol et al. 2008; Dai et al. 2005; Chen et al. 2013). Leaching is one of the primary pathways for trace elements to enter into the ecosystem (Yang et al. 2016, Baruah et al. 2004). Swaine (2000) proposed the possibility of the presence of twenty six trace elements in coal that have potential environmental impacts, including $\mathrm{As}, \mathrm{Cr}, \mathrm{Cd}, \mathrm{Hg}, \mathrm{Pb}, \mathrm{Se}, \mathrm{B}, \mathrm{Mn}, \mathrm{Ni}, \mathrm{Cu}, \mathrm{V}, \mathrm{Zn}, \mathrm{Co}$, $\mathrm{Sn}, \mathrm{Cl}, \mathrm{F}, \mathrm{Br}, \mathrm{Mo}, \mathrm{P}, \mathrm{Th}, \mathrm{U}, \mathrm{Ba}, \mathrm{Ra}, \mathrm{Sb}$ and Tl. Out of these elements $\mathrm{As}, \mathrm{Cd}, \mathrm{Hg}, \mathrm{Pb}, \mathrm{Cr}$ and $\mathrm{Se}$ are of greater environmental importance (Swaine 2000; Prachiti et al. 2011; Singh et al. 2015a, b). Most of the Se in coal is associated with organic constituents; however, some of the Se is also associated with the sulfide minerals of coal, mainly pyrite (Swaine 1990). In coal, Cd is predominantly associated with Sphalerite (ZnS) (Alper et al. 2008). Lead (Pb) occurs in coal mainly as the sulfide mineral galena $(\mathrm{PbS})$ which is the most common form of lead in coal (Finkelman 1994; Swaine 1990). These trace elements present in coal and its mine rejects/overburden enter into the environment through different processes including leaching of coal and oxidation of pyrite (Equeenuddin 2015). Coal dumps are also an important factor in the environmental degradation because the potentially toxic elements are directly released to the environment through the leaching and oxidation of pyrite. To understand the release of potential hazardous elements (PHE's) from coal and coal mine rejects in potential environmental and ecological conditions, the leaching behavior of coal and mine rejects in open cast coal mining is important. During the coal mining activities, the pyrite present in coal is exposed and comes into contact with the atmospheric oxygen, moisture or rain water. This weathering process leads to the generation of AMD. AMD generation and metal leaching processes from coal and mine $\mathrm{OB}$ are natural processes. These processes are accelerated by intensification of mining operations (Banerjee 2014). Such mining activities have a detrimental effect on the local environment as well as on the ecology (Kimmel 1983; Johnson 1987; Kaeser and Sharpe 2001).

Due to the formation of sulfuric acid by exposing pyrite to atmospheric oxygen and water, acid mine drainage is generated in coal mining areas. The metals in coal and coal wastes, which are minerals associated with the inorganic part of the coal structure are easily dissolved in highly acidic AMD. Thus, the AMD (pH 2.0-3.0) (Baruah et al. 2006; Dowarah et al. 2009) has a strong leaching potential for releasing a large number of potentially PHE's into the aquatic environment. In addition to the AMD formation, under different atmospheric conditions, pyrite $\left(\mathrm{FeS}_{2}\right)$ in coal is often found in association with the hazardous elements such as $\mathrm{As}, \mathrm{Cd}, \mathrm{Cu}, \mathrm{Co}, \mathrm{Pb}, \mathrm{Hg}$, and $\mathrm{Zn}$ (Monterroso and Macias 1998; Singh et al. 2016). The formation of elemental sulfur takes place during depyritization of coal by leaching of coal wastes (Schippers et al. 1996). The leachates generated from $\mathrm{OB}$ dumps are rich in heavy metals, especially $\mathrm{Fe}, \mathrm{Cu}, \mathrm{Mn}$ and $\mathrm{Ni}$ (Tiwari 2001). The leaching property of different elements depends on several factors like specific element solubility and availability or release potential (Moyo et al. 2012). Also the other factors that enhance the metal leaching include swiftly weathering metal containing minerals and the mine drainage conditions that can increase the solubility and flow rates through the contaminated minerals (Banerjee 2014).

The sulfur present in Northeastern (NER) Indian coal is mainly in three forms-sulfate sulfur, pyritic sulfur, and organic sulfur (Baruah and Gogoi 1998). The major part of the inorganic sulfur present in coal is in pyrite $\left(\mathrm{FeS}_{2}\right)$. The Northeastern Indian coals are rich in sulfur (2\%-11\%) (Chabukdhara and Singh 2016; Singh et al. 2012b, 2013). The sulfate formed from pyritic sulfur in coal by atmospheric oxygen is not only responsible factor for AMD generation but the oxidation of $\mathrm{Fe}(\mathrm{II})$ ion to $\mathrm{Fe}$ (III) ion during the process of weathering of pyrite can produce a noticeable amount of AMD (Baruah et al. 2006). Equeenuddin (2015) reported that coal dumps cause environmental degradation due to the release of potentially hazardous elements through the process of leaching of pyrite. The amount of impact of waste and coal containing contaminants in a form of toxic elements on the environment depend not only on the type and concentrations of 
these elements, but mainly on their mobility. The mobility of pollutants contained in the waste is expressed as the potentiality of them to leach in water (Kalembkiewicz and Palczak 2015). Leaching methods are classified into two types depending upon whether the leaching liquid is added at a single instance (static) or it is renewed (dynamic) (Moyo et al. 2011). The potential to produce acidity of drainage from mine water and mine wastes can be predicted by both geochemical methods in static and kinetic leaching processes (Ferguson and Erickson 1998). The static methods are further classified into two classes, batch leaching where a specific amount of sample is placed in a given amount of leachant solution (US DOE 2005; Hesbach et al. 2005; Kim et al. 2003) and column leaching.

Thus, the quality of surface and ground water in the streams, drains, well, contaminated with AMD water and leachates of coal and overburden was also analyzed to study the possible impact of coal mining on the nearby water resources. During leaching, the elements present in coal and OB dissolve or undergo some chemical and physical reactions and as a result they transfer into the leaching solution (Fotoupoulou et al. 2010; Wang et al. 1999). In the present work, the static aqueous leaching experiments are mainly carried out to evaluate the potential of release of selected metals. The aqueous leaching experiments of different coal and overburden samples, from the Ledo colliery are carried out and the results are also compared with those of field data.

\subsection{Study area}

The Makum coalfield is the largest coalfield among all the coalfields of the Northeastern region (NER) of India. The coalfield is located in the Tinsukia district of Assam and includes five working collieries namely Ledo, Baragolai, Tirap, Tikak, and Tipong. Among them, Ledo is the most recent and active colliery where open cast mining activities are operational. The mining area in Ledo-Margherita range is located within $27^{\circ} 15^{\prime}-27^{\circ} 25^{\prime} \mathrm{N}$ latitudes and $95^{\circ} 40^{\prime}-$ $95^{\circ} 50^{\prime} \mathrm{E}$ longitudes which includes the probable mine affected area. In this study, the nearby areas influenced by the Ledo open cast mining activities have also been chosen. The chosen area extends from Ledo mining area to the Tirap mining area including the Tirap River, Ledopani River, and Kachanalla River. The areas near the Kachanalla and Tirap rivers are large agricultural areas with a tea garden, rural habitation area, and a colony of mining workers. A number of streams and ponds are also found which come across the mine area. The major sources for drinking water for the people of these areas are tube-wells and dig-wells. A location map of the study areas is shown in the Fig. 1.

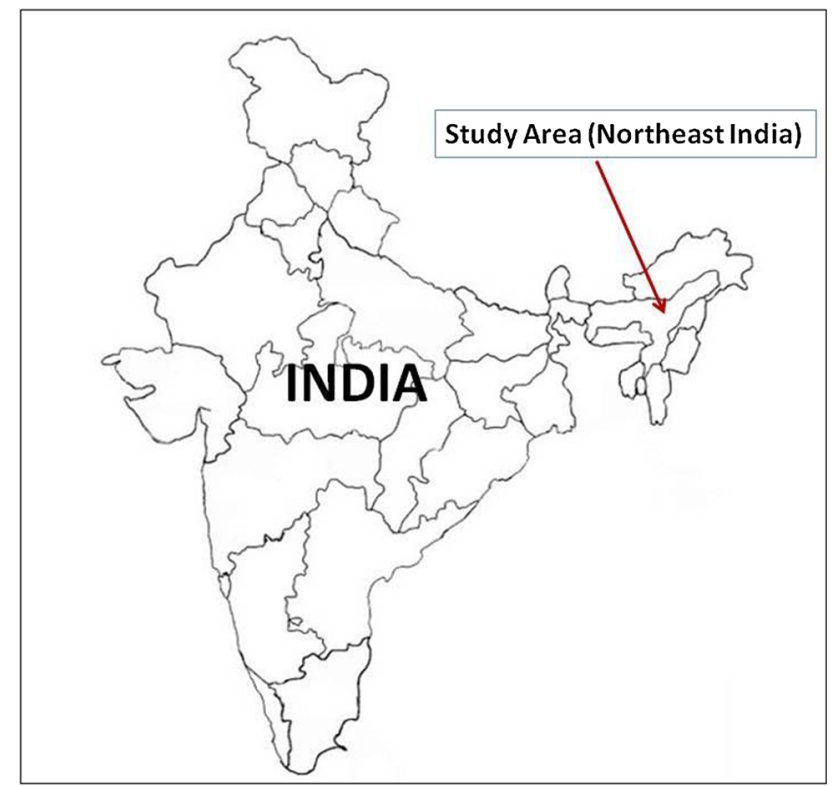

Fig. 1 Map showing the location of Ledo colliery (study area) in Northeast India region (not to scale)

\section{Experimental sections}

\subsection{Sampling and aqueous leaching}

Freshly mined representative coal samples (LC-20A, LC60A) and overburden samples (LOB-15A, LOB-15B) (dump sites) were collected from the Ledo colliery (India). The coal and overburden samples were ground into-72 BS $(0.211 \mathrm{~mm})$ size, preserved in a desiccator for subsequent experiments. Mine water samples (LW-15A, LW-15B, LW-15C, LW-15D, LW-15E, and LW-15F) were also collected from the AMD source and from different points within the $5 \mathrm{~km}$ radius from the mining source of the Ledo colliery as shown in Fig. 2.

$100 \mathrm{~g}$ of each finely ground sample was mixed with distilled water $(300 \mathrm{ml})$ for $1,3,5$, and $8 \mathrm{~h}$ at $25,45,65$, and $90{ }^{\circ} \mathrm{C}$ respectively. Then the mixture was mechanically stirred in an electronic shaker (VELP, Scintifica JLT6) for the time periods $1,3,5$, and $8 \mathrm{~h}$ at a stirring rate of $250 \mathrm{rpm}$. The supernatant liquid was filtered from the solid phase with a Whatmann-1 filter paper. The filtrate was collected and used for different physical, chemical, and elemental analyses. The residues of the leached samples were also subjected to selected chemical analyses as mentioned in later part.

\subsection{Physico-chemical analysis of aqueous leachates}

The aqueous leachates of the coal and overburden (OB) samples obtained were subjected to $\mathrm{pH}$, TDS (total 


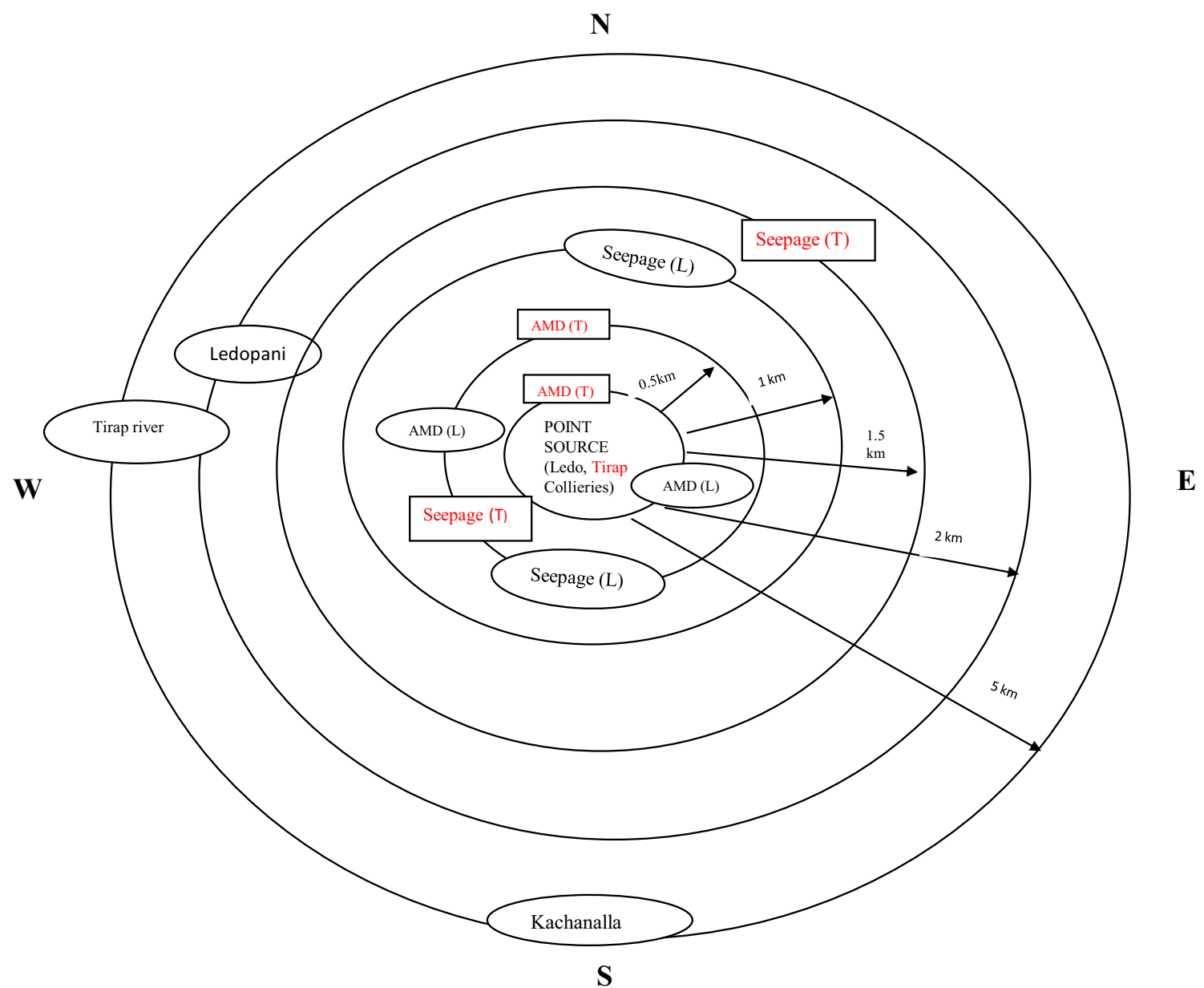

Fig. 2 Schematic diagram showing the actual sampling locations in around Ledo colliery (Open cast mining)

dissolved solid), and EC (electrical conductivity) analysis by using a EUTECH PC700 pH/EC/TDS meter.

\subsection{Chemical analysis of aqueous leachates}

\subsubsection{Ion-chromatographic analysis}

Ion-chromatographic (IC) analysis of the aqueous leachates of coal and overburden samples at different time and temperatures were subjected to IC analysis to determine the concentrations of different cations and anions (in ppm) by using an ion chromatography system-Metrohm 882 Compact IC Plus using standards purchased from Merck and Sigma Aldrich. Before analysis, the liquid samples were filtered through $0.22 \mu \mathrm{m}$ Millipore filter paper. The anions were analyzed using $4 \mathrm{~mm} \times 250 \mathrm{~mm}$ Metrosep A Supp 5 analytical column with the chemical suppression sulfuric acid and Metrosep RP2 3.5 guard column. Similarly, the cations were analyzed using a $4 \mathrm{~mm} \times 150 \mathrm{~mm}$ Metrosep C-4 analytical column and Metrosep RP2 3.5 guard column.

\subsubsection{Inductively coupled plasma optical emission spectrometry (ICP-OES) and atomic absorption spectrometry $(A A S)$}

The trace elements were determined by using an inductively coupled plasma optical emission spectrometry (ICPOES). In this process $0.2 \mathrm{~g}$ from reference material for digestion was used. Wet digestion of samples was performed using $5 \mathrm{ml}$ mixtures of acids: $\mathrm{HNO}_{3}: \mathrm{HClO}_{4}(3: 1)$. Each sample was heated up to $180{ }^{\circ} \mathrm{C}$ for $3.0 \mathrm{~h}$ (sample should be transparent) on the heating digestion block. Then the acid digest sample was allowed to cool and filtered into a $25 \mathrm{~mL}$ volumetric flask, using Whatmann filter paper and made up to mark with de-ionised water. The blank digests sample was similarly processed. The digested samples were followed by ICP-OES, (Perkin Elmer, Optima $5300 \mathrm{~V}$ ).Calibration curves for elements were created from mixtures of high-purity element standard solutions (Merck, Germany) in a $4 \%(\mathrm{v} / \mathrm{v}) \mathrm{HNO}_{3}$ matrix.

Atomic absorption spectrometry (AAS), flame atomic absorption spectrometry (FAAS), and graphite furnace 
atomic absorption spectrometry (GFAAS) analytical methods were used to detect different elements. GAAS is based on the same principles as FAAS with the main difference in the atomization of the samples. Instead of the flame in FAAS, the GFAAS uses an electro thermal atomizer (a small graphite tube). The samples were prepared for both analyses by digesting the samples with $\mathrm{HNO}_{3}-$ $\mathrm{H}_{2} \mathrm{O}_{2}$ in a ratio of $4: 1$ using microwave assisted acid digestion process. For FAAS analytical method, different standard solutions were used like Fe [(p/n 8003-0906), Zn (p/n 8003-0942)], Cu (p/n 5190-8280). In GFAAS analytical method, stock standard solutions are prepared from analytical reagent grade high purity metals, oxides, or nonhygroscopic salts using reagent water and redistilled $\mathrm{HNO}_{3}$ or $\mathrm{HCl}$.

\subsubsection{X-ray diffraction analysis}

X-ray diffraction analysis (XRD) of the samples were carried out in an X-ray diffractometer, model JDXII PZA, JEOL, Japan, using $\mathrm{Cu} \mathrm{K} \alpha \mathrm{Fe}$-filtered X-ray radiation ( $\lambda=1.5426 \AA$ ) to study the presence of different minerals in the leached samples. Operating parameters were as follows: start angle: 5.0, target: $\mathrm{Cu}$ (Fe-filtered), stop angle: 80.0, measuring time: 0.5 and step angle: 0.03 , data processing conditions included: smoothing points, Goniometer radius $(R)$ : $240 \mathrm{~mm}$, equatorial angle subtended at the specimen by the detector slit $(\beta): 1^{\circ}$.

\subsubsection{Fourier transform infrared spectroscopy analysis}

The Fourier transform infrared spectroscopy (FTIR) analyses of the leached samples were done by using PerkinElmer system 2000, model 640B with $\mathrm{KBr}$ pellet. The detector used was deuterated triglycine sulphate (DTGS). The total number of scans was 50 with the spectral resolution of $4 \mathrm{~cm}^{-1}$ during the recording of the spectra. The samples were subjected to FTIR analyses to determine the presence of different functional groups, including sulfur containing groups.

\subsubsection{Field emission-scanning electron microscopic analysis}

Field emission-scanning electron microscopy (FESEM) provides elemental information at magnifications of $10 \times-$ $300,000 \times$ with virtually unlimited depth of field. Compared with convention scanning electron microscopy (SEM), field emission SEM provides clearer, less electrostatically distorted images with spatial resolution down to $11 / 2 \mathrm{~nm}$ - three to six times better. Field emission scanning electron microscopy (FESEM) images were obtained from a Carl Zeiss Sigma FESEM instrument. Energy dispersive X-ray spectroscopy (EDS) pattern and elemental mapping analysis was recorded on Oxford X Max 20 equipment.

\section{Results}

\subsection{Physico-chemical characteristics of aqueous leachates}

The physico-chemical parameters including $\mathrm{pH}, \mathrm{EC}$, and TDS were determined for the aqueous leachates obtained at increasing time intervals and temperatures. Table 1 shows that the $\mathrm{pH}$ values of the leachates of the samples decreased gradually from $1 \mathrm{~h}$ of leaching to $5 \mathrm{~h}$ of leaching time at room temperature. The $\mathrm{pH}$ of the leachates however increased slightly at $8 \mathrm{~h}$ of leaching time. The leaching at $45^{\circ} \mathrm{C}$ for $1,3,5$ and $8 \mathrm{~h}$ respectively demonstrate a gradual increase in $\mathrm{pH}$ values. The electrical conductivity (EC) of the aqueous leachates of the samples at room temperature $\left(25^{\circ} \mathrm{C}\right)$ gradually increased from 1 to $8 \mathrm{~h}$ of leaching. Similarly, the TDS values were found to increase gradually with increase in time period of leaching and with increase in leaching temperature (from room temperature to $45^{\circ} \mathrm{C}$ ). Various physico-chemical properties of the aqueous leachates of coal and $\mathrm{OB}$ samples are given subsequently. The $\mathrm{pH}$ of the leachates (leached in different time periods at different temperature) from the Ledo coal is highly acidic ( $\mathrm{pH} 2.5)$ while other $\mathrm{OB}$ samples release a nearly neutral discharge (4-7.4). In the cases of leaching at a temperature higher than room temperature $\left(45^{\circ} \mathrm{C}\right)$, the $\mathrm{pH}$ increased up to 9.40 .

\subsection{Elemental characteristics of aqueous leachates}

\subsubsection{Ions present in the aqueous leachates of coals and overburdens}

The Ion-Chromatographic analyses were carried out for aqueous leachates of coal and overburden samples after leaching for $1,3,5$, and $8 \mathrm{~h}$ at 25,45 and $65^{\circ} \mathrm{C}$ respectively. The concentration of cations like $\mathrm{Na}^{+}, \mathrm{Mg}^{2+}, \mathrm{Ca}^{2+}$, $\mathrm{NH}_{4}{ }^{+}$and $\mathrm{Li}^{+}$in the leachates of coal and overburden decreased with an increase in leaching temperature (Figs. 3, 4, 5, 6, 7, 8, 9, 10). The leaching of $\mathrm{Li}^{+}$ion in aqueous solution is found to be decreased with leaching time from 1 to $8 \mathrm{~h}$ as shown in Table S5 (see in supplementary information).

From Figs. 11, 12, 13 and 14, it can be observed that the concentrations of $\mathrm{F}^{-}, \mathrm{Cl}^{-}$and $\mathrm{SO}_{4}{ }^{2-}$ ions from the leachates of coal and overburden samples of Ledo colliery increased with an increase in the leaching time at room temperature. With the increase in leaching temperature 
Table 1 Physical analysis of aqueous leachates at room temperature at different leaching times

\begin{tabular}{|c|c|c|c|c|c|}
\hline Sample type & Sample code & Leaching time (h) & $\mathrm{pH}$ & TDS (ppm) & $\mathrm{EC}(\mu \mathrm{s} / \mathrm{cm})$ \\
\hline \multirow[t]{8}{*}{ Coal } & LC-20A & 1 & 1.99 & 989 & 1912 \\
\hline & LC-60A & & 2.65 & 106 & 209 \\
\hline & LC-20A & 3 & 1.80 & 983 & 1970 \\
\hline & LC-60A & & 2.27 & 119 & 238 \\
\hline & LC-20A & 5 & 1.62 & 1003 & 2006 \\
\hline & LC-60A & & 3.52 & 106.9 & 210 \\
\hline & LC-20A & 8 & 2.10 & 790 & 313 \\
\hline & LC-60A & & 3.50 & 213 & 106 \\
\hline \multirow[t]{8}{*}{ Overburden } & LOB-15A & 1 & 6.72 & 120 & 242 \\
\hline & LOB-15B & & 5.85 & 24.2 & 48.6 \\
\hline & LOB-15A & 3 & 4.76 & 129 & 129 \\
\hline & LOB-15B & & 6.92 & 89.2 & 89.2 \\
\hline & LOB-15A & 5 & 3.68 & 240 & 480 \\
\hline & LOB-15B & & 3.71 & 186 & 373 \\
\hline & LOB-15A & 8 & 5.36 & 139 & 278 \\
\hline & LOB-15B & & 6.30 & 69.5 & 129.5 \\
\hline
\end{tabular}

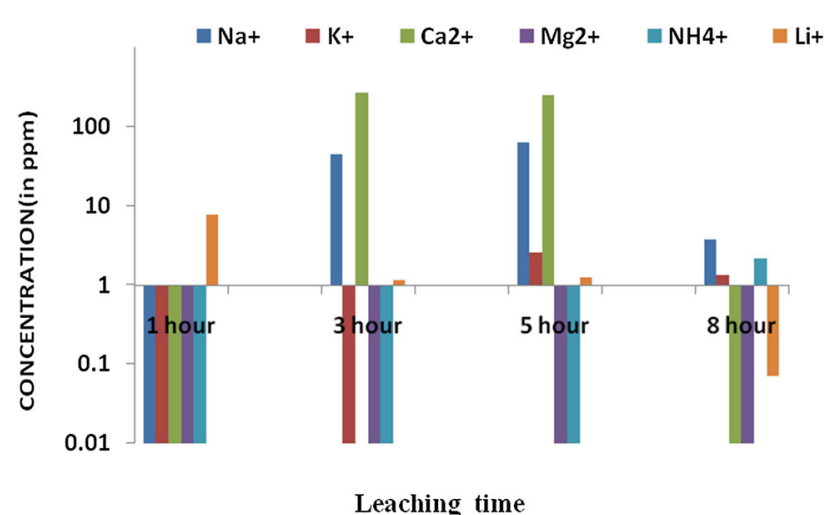

Fig. 3 Change in concentration (in ppm) of cations in aqueous leachates of Ledo coal (LC-20A) with leaching time (in hour) at $25{ }^{\circ} \mathrm{C}$

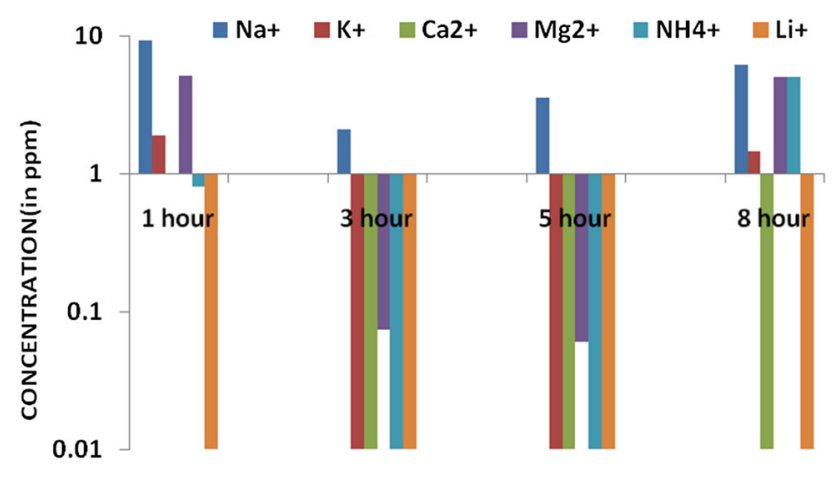

Leaching time

Fig. 4 Change in concentration (in ppm) of cations in aqueous leachates of Ledo coal (LC-60A) with leaching time (in hour) at $25{ }^{\circ} \mathrm{C}$

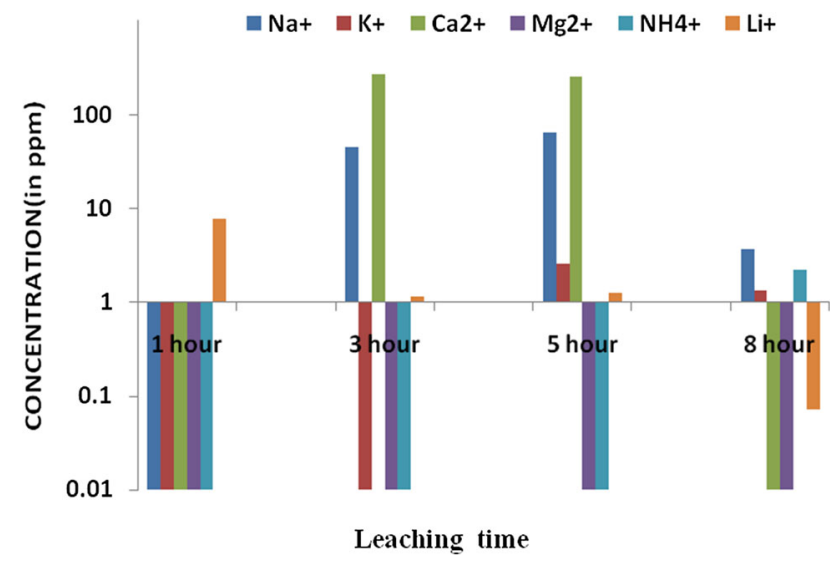

Fig. 5 Change in concentration (in ppm) of cations in aqueous leachates with leaching time (in hour) of Ledo overburden (LOB$15 \mathrm{~A})$ at $25^{\circ} \mathrm{C}$

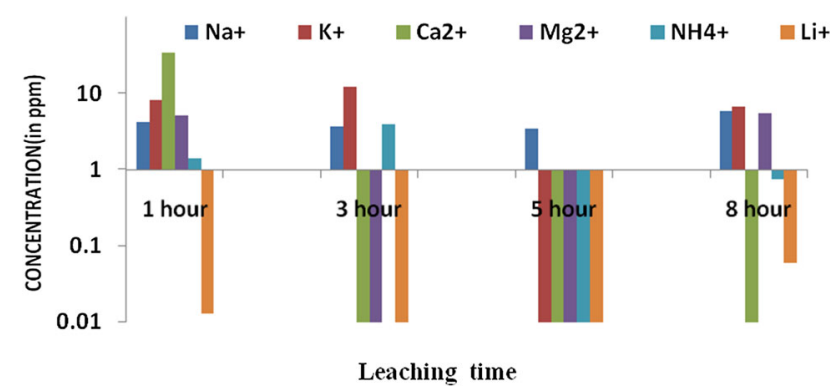

Fig. 6 Change in concentration of cations (in ppm) in aqueous leachates of Ledo overburden (LOB-15B) with leaching time (in hour) at $25{ }^{\circ} \mathrm{C}$ 


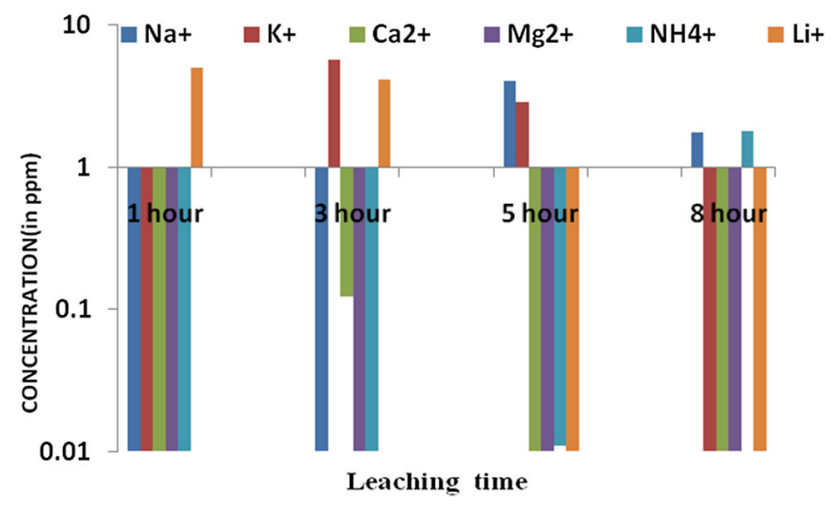

Fig. 7 Change in concentration of cations (in $\mathrm{ppm}$ ) in aqueous leachates of Ledo coal (LC-20A) with leaching time (in hour) at $45{ }^{\circ} \mathrm{C}$

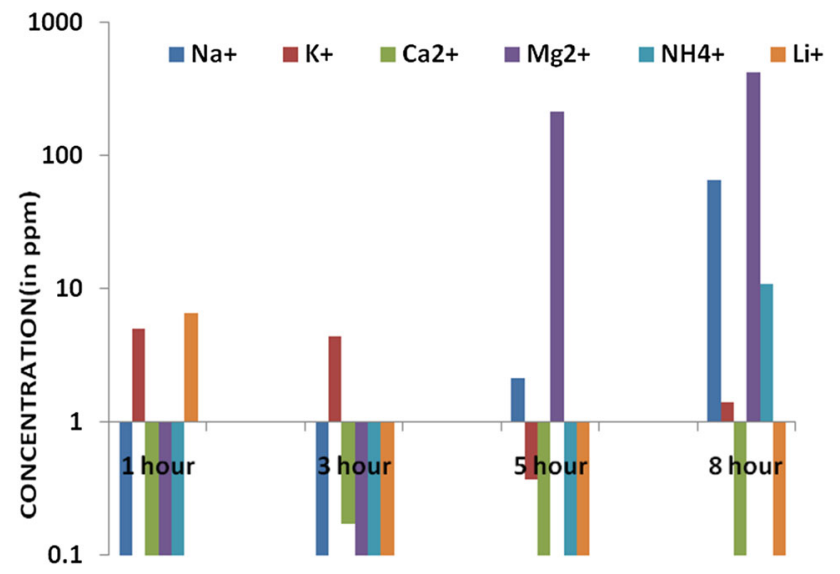

Leaching time

Fig. 8 Change in concentration of cations (in ppm) in aqueous leachates of Ledo coal (LC-60A) with leaching time (in hour) at $45{ }^{\circ} \mathrm{C}$

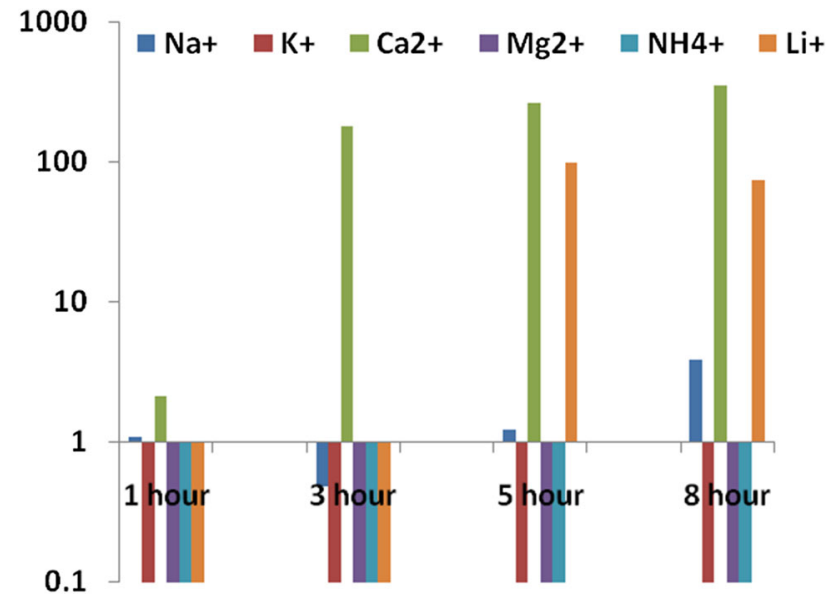

Fig. 9 Change in concentration of cations (in ppm) in aqueous leachates of Ledo coal (LC-20A) with leaching time (in hour) at $65{ }^{\circ} \mathrm{C}$

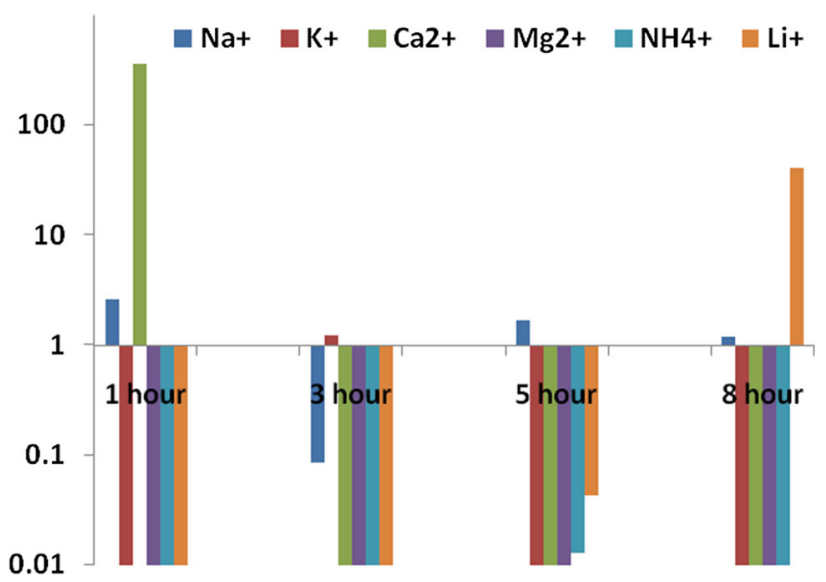

Fig. 10 Change in concentration of cations (in ppm) in aqueous leachates of Ledo coal (LC-60A) with leaching time at $65{ }^{\circ} \mathrm{C}$

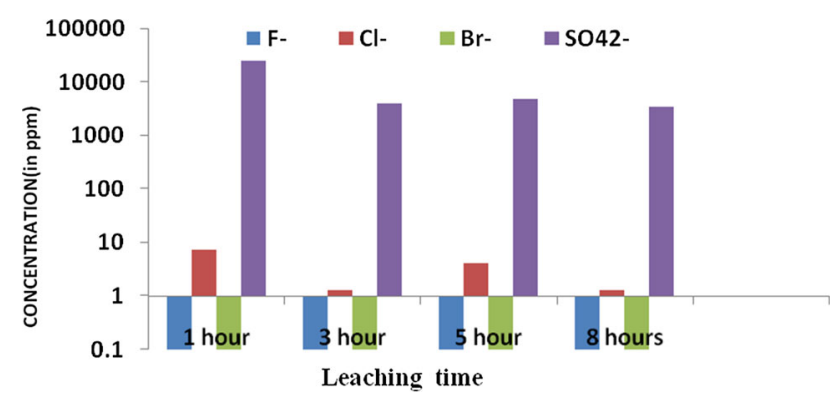

Fig. 11 Change in concentration (in ppm) of anions in aqueous leachates of Ledo coal (LC-20A) with leaching time (in hour) at $25^{\circ} \mathrm{C}$

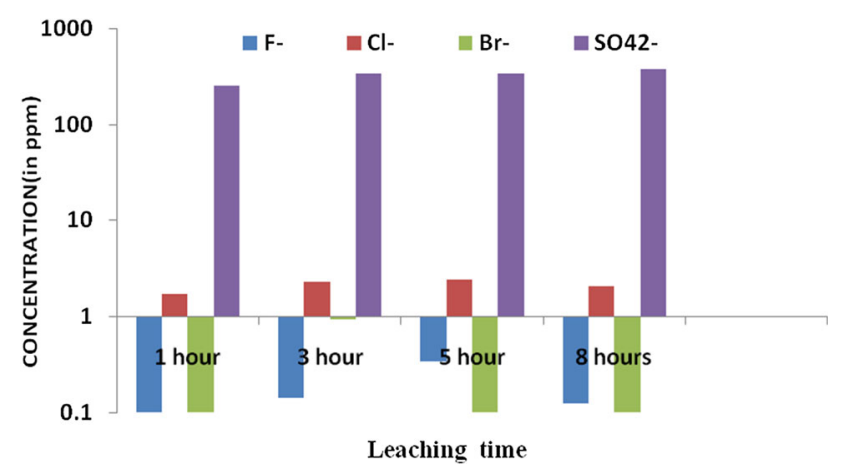

Fig. 12 Change in concentration (in ppm) of anions in aqueous leachates of Ledo coal (LC-60A) with leaching time (in hour) at $25^{\circ} \mathrm{C}$

from 25 to $45{ }^{\circ} \mathrm{C}$ however, the concentration of $\mathrm{F}^{-}, \mathrm{Cl}^{-}$ became lower (Figs. 15, 16, 17, 18). The leaching of $\mathrm{SO}_{4}{ }^{2-}$ ion from coal and overburden was increased with leaching temperature from 25 to $65^{\circ} \mathrm{C}$ and time (see Figs. 15, 16, 17, 18, 19, 20, 21, 22). 


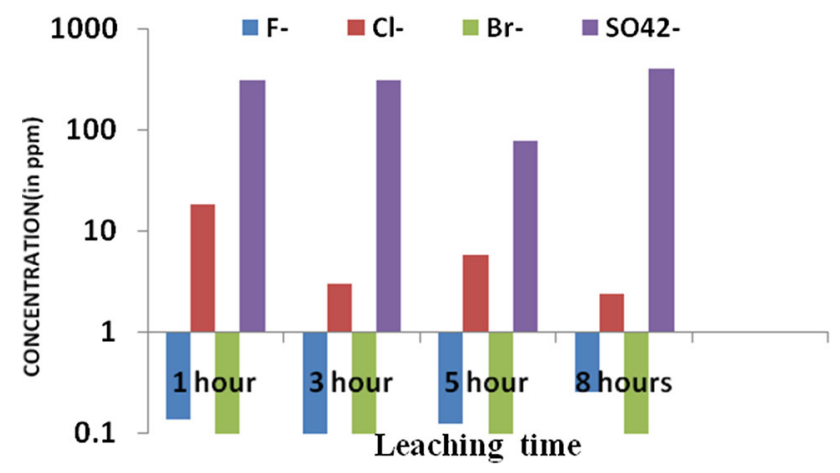

Fig. 13 Change in concentration (in ppm) of anions in aqueous leachates of Ledo overburden (LOB-15A) with leaching time (in hour) at $25{ }^{\circ} \mathrm{C}$

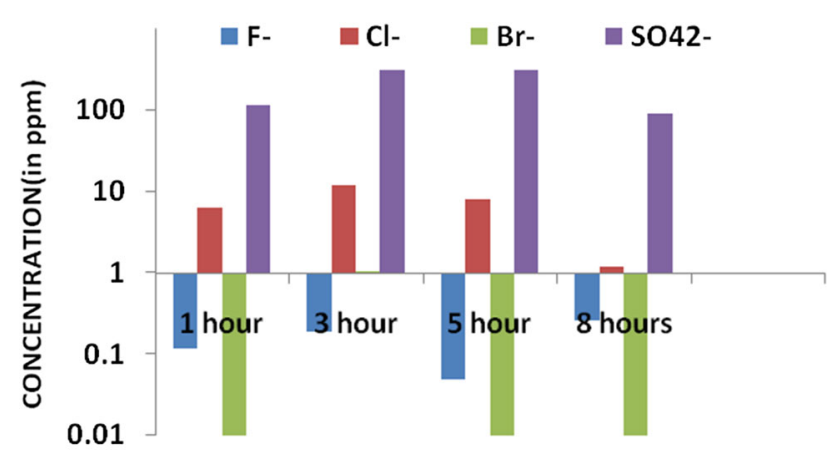

Leaching time

Fig. 14 Change in concentration (in ppm) of anions in aqueous leachates of Ledo overburden (LOB-15B) with leaching time (in hour) at $25{ }^{\circ} \mathrm{C}$

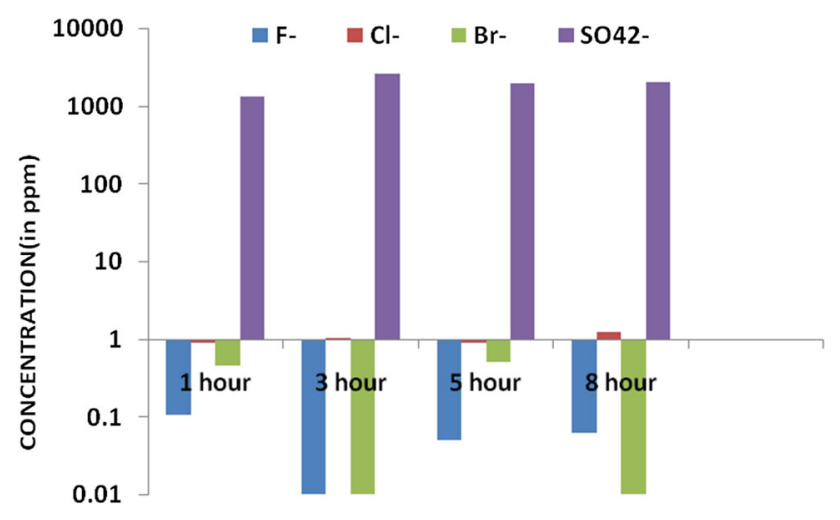

Leaching time

Fig. 15 Change in concentration (in ppm) of anions in aqueous leachates of Ledo coal (LC-20A) with leaching time (in hour) at $45{ }^{\circ} \mathrm{C}$

\subsubsection{Major, minor, and trace/hazardous elemental analysis}

The mode of occurrence of an element plays an important role for prediction of its nature during the process of

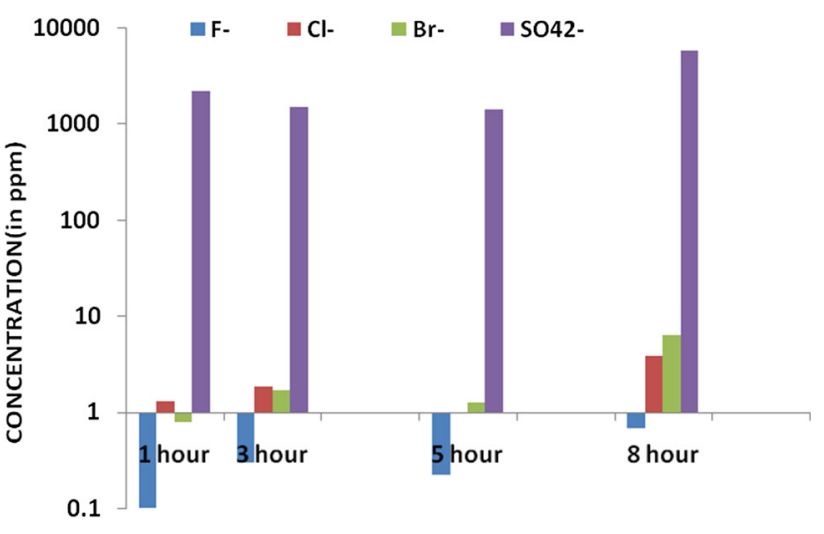

Leaching time

Fig. 16 Change in concentration (in ppm) of anions in aqueous leachates of Ledo coal (LC-60A) with leaching time (in hour) at $45{ }^{\circ} \mathrm{C}$

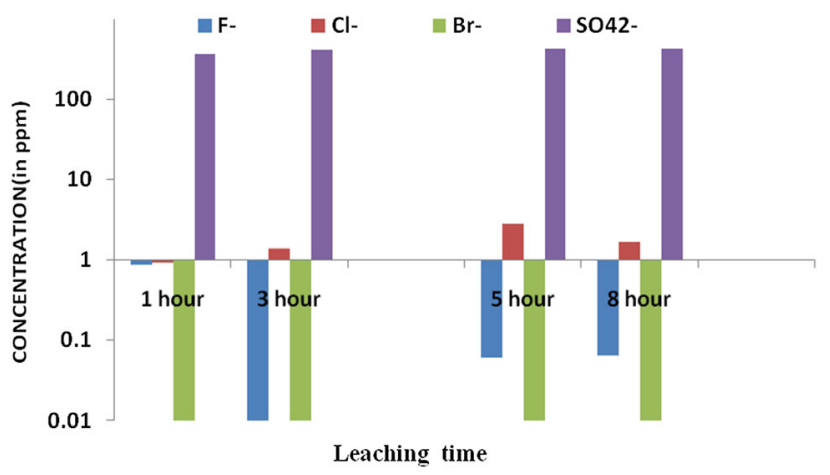

Fig. 17 Change in concentration (in ppm) of anions in aqueous leachates of Ledo overburden (LOB-15A) with leaching time (in hour) at $45{ }^{\circ} \mathrm{C}$

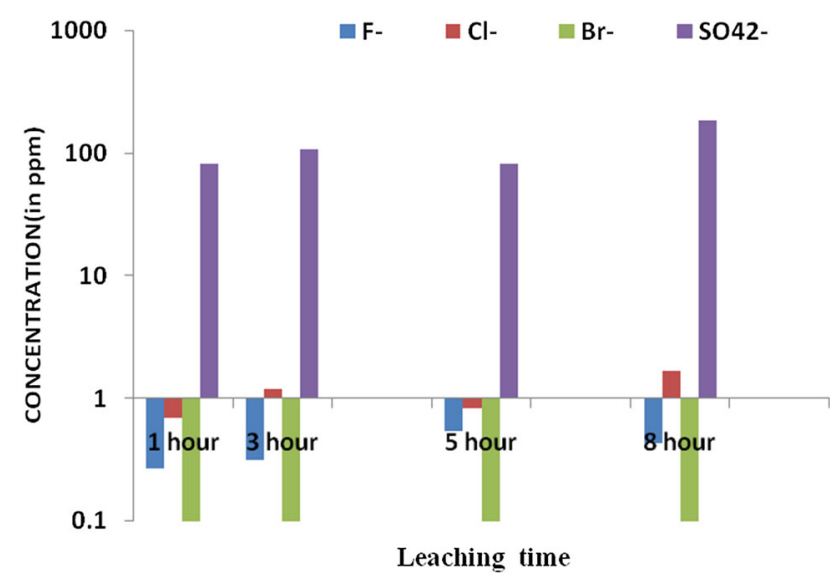

Fig. 18 Change in concentration (in $\mathrm{ppm}$ ) of anions in aqueous leachates of Ledo overburden (LOB-15B) with leaching time (in hour) at $45{ }^{\circ} \mathrm{C}$

leaching. The modes of occurrences of major elements like $\mathrm{Al}, \mathrm{Ca}, \mathrm{Fe}, \mathrm{Mg}, \mathrm{Na}, \mathrm{K}$, etc., minor element $\mathrm{Mn}$ and the trace/hazardous elements $\mathrm{As}, \mathrm{Ba}, \mathrm{Cd}, \mathrm{Cr}, \mathrm{Co}, \mathrm{Ni}, \mathrm{Cu}, \mathrm{Pb}$, 


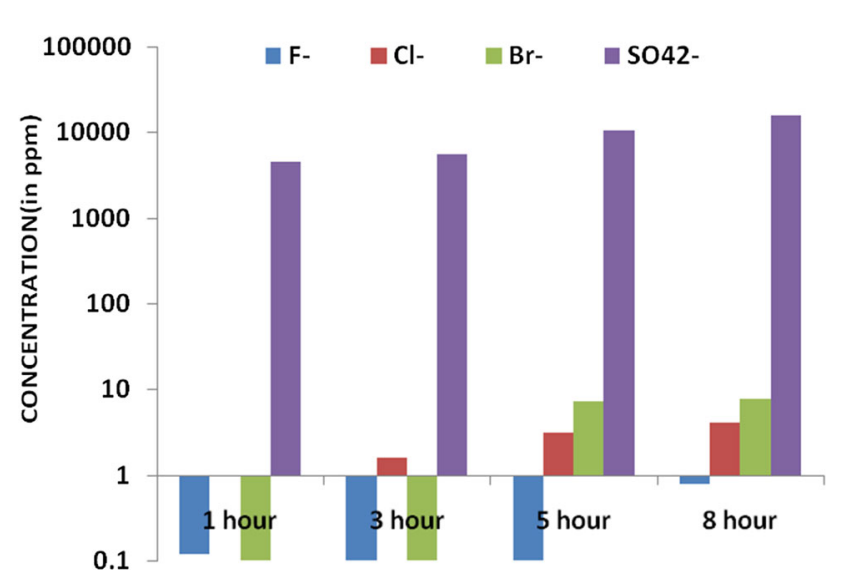

Leaching time

Fig. 19 Change in concentration (in ppm) of anions in aqueous leachates of Ledo coal (LC-20A) with leaching time (in hour) at $65{ }^{\circ} \mathrm{C}$

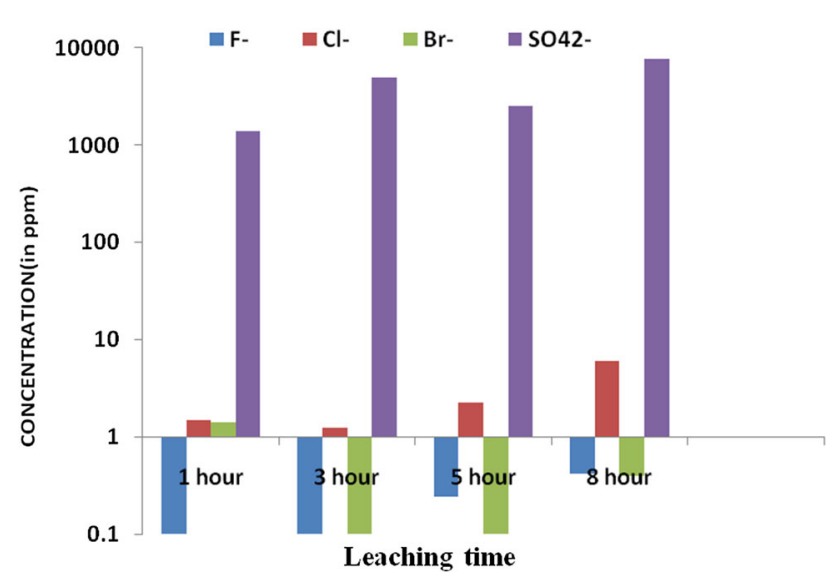

Fig. 20 Change in concentration (in ppm) of anions in aqueous leachates of Ledo coal (LC-60A) with leaching time (in hour) at $65{ }^{\circ} \mathrm{C}$

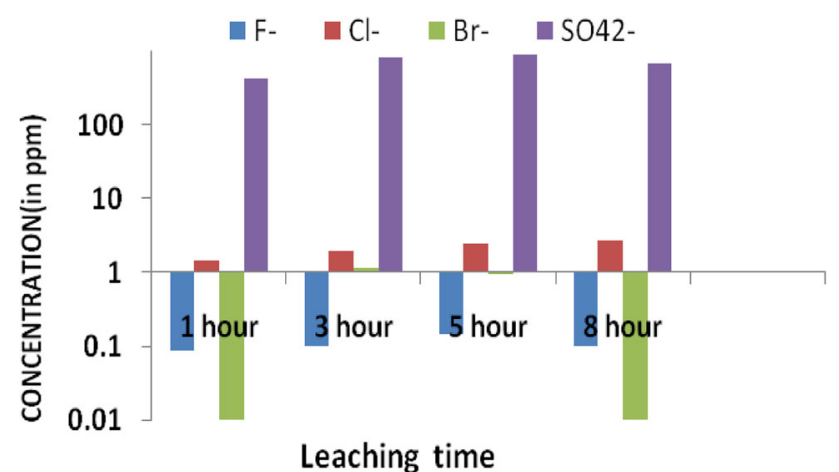

Fig. 21 Change in concentration (in ppm) of anions in aqueous leachates of Ledo $\mathrm{OB}$ (LOB-15A) with leaching time (in hour) at $65{ }^{\circ} \mathrm{C}$

$\mathrm{Hg}, \mathrm{Ni}$ and $\mathrm{Zn}$ as well as the minerals in coal can vary from coal to coal and according to their association in coal, the concentration of various elements in aqueous leachates can

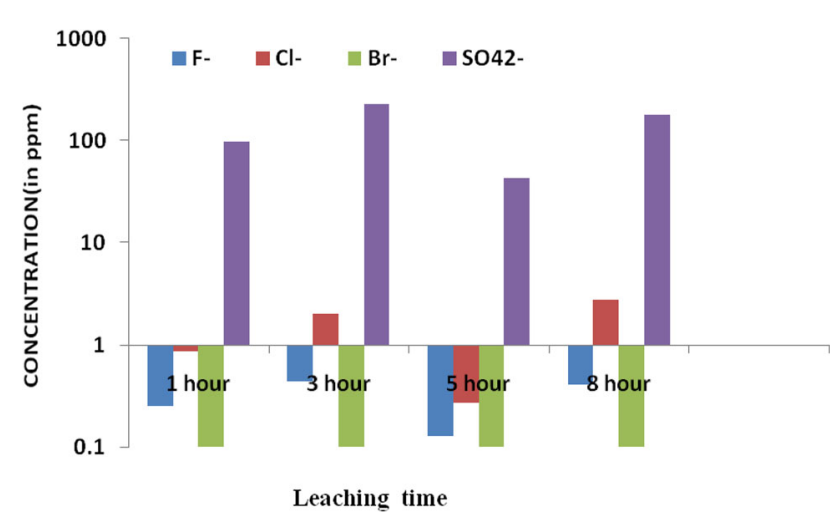

Fig. 22 Change in concentration (in ppm) of anions in aqueous leachates of Ledo OB (LOB-15B) with leaching time (in hour) at $65{ }^{\circ} \mathrm{C}$

be detected. In most of the coals, the metals occur as mineral matters, or as discrete minerals, or as free or embedded in organic matter (Swain and Goodarzi 1995). From nano-mineralogical analysis of Northeast Indian coal and overburden samples, it was found that the Si minerals like kaolinite $\left[\mathrm{Al}_{2} \mathrm{Si}_{2} \mathrm{O}_{5}(\mathrm{OH})_{4}\right]$, sulphate minerals such as barite $\left[\mathrm{BaSO}_{4}\right]$, jarosite $\left.\left[\mathrm{KFe}_{3}\left(\mathrm{SO}_{4}\right)_{2}(\mathrm{OH})_{6}\right)\right]$, pickeringite $\left[\mathrm{MgAl}_{2}\left(\mathrm{SO}_{4}\right)_{4} \cdot 22\left(\mathrm{H}_{2} \mathrm{O}\right)\right]$, sulphide mineral galena $[\mathrm{PbS}]$, pyrite $\left[\mathrm{FeS}_{2}\right]$, and oxide mineral hematite $\left[\mathrm{Fe}_{2} \mathrm{O}_{3}\right]$, are most common minerals which contains elements in their matrix. The presence of minerals like illite $(\mathrm{K}$, $\left.\mathrm{H}_{2} \mathrm{O}\right)(\mathrm{Al}, \mathrm{Mg}, \mathrm{Fe})_{2}(\mathrm{Si}, \mathrm{Al})_{4} \mathrm{O}_{10}\left[(\mathrm{OH})_{2} \cdot\left(\mathrm{H}_{2} \mathrm{O}\right)\right]$ and marcasite $\left(\mathrm{FeS}_{2}\right)$ in Northeast Indian coals are also reported by Mossbauer spectroscopic analysis elsewhere (Dutta et al. 2017).

The ICP-OES analysis of the aqueous leachates of the coal reveals that the concentration of different elements like $\mathrm{Al}, \mathrm{Ba}, \mathrm{Co}, \mathrm{Ni}, \mathrm{Fe}, \mathrm{Mn}, \mathrm{Cu}$, and $\mathrm{Zn}$ increased with

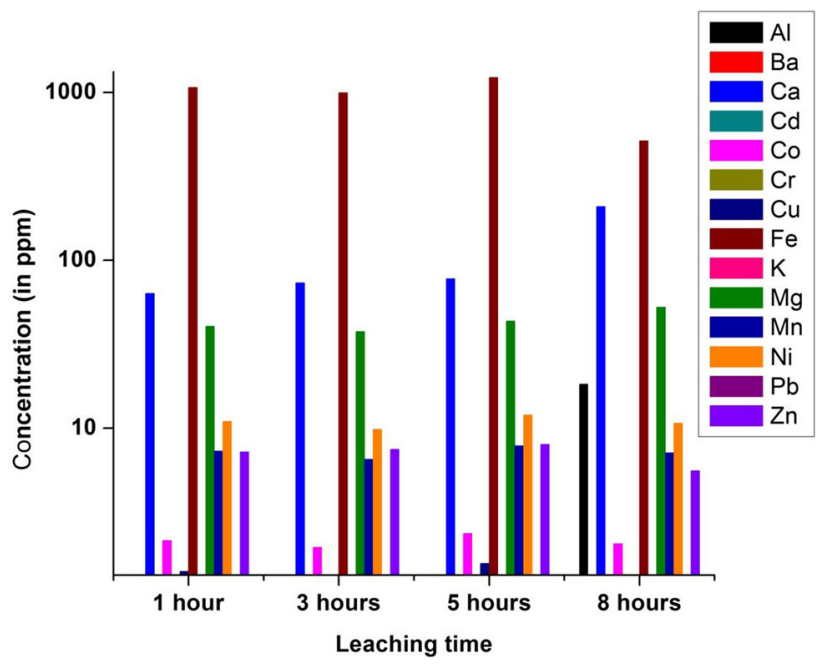

Fig. 23 Change in elemental concentration (in ppm) in aqueous leachates of Ledo coal (LC-20A) with leaching time (in hour) at $25{ }^{\circ} \mathrm{C}$ 
leaching time at room temperature $\left(25^{\circ} \mathrm{C}\right)$ (Figs. 23, 24). From Figs. 23, and 24, it is found that the concentrations of major elements like $\mathrm{Al}, \mathrm{Fe}$, etc., minor element $\mathrm{Mn}$ and trace/hazardous elements like $\mathrm{Ba}, \mathrm{Co}, \mathrm{Ni}, \mathrm{Cu}, \mathrm{Zn}$, etc. increased with leaching time at room temperature $\left(25^{\circ} \mathrm{C}\right)$. The rates of leaching of each element from raw coals are also indicated in Tables S23 and S24 (See supplementary information). The leaching property of $\mathrm{Ni}$ is temperature as well as leaching time dependent as shown in Figs. 23, 24, 25, 26, 27 and 28. The increase rates of leaching of $\mathrm{Ni}$ with time and temperature are indicated in Tables S23, S24, S25, S26, S27 and S28 (details are in supplementary information). Here the concentration of $\mathrm{Ni}$ in the aqueous leachates of coal is maximum at leaching time of $8 \mathrm{~h}$. In the case of $\mathrm{Fe}, \mathrm{Mn}, \mathrm{Cu}, \mathrm{Zn}, \mathrm{Ca}$ and $\mathrm{Mg}$ the concentration was found to increase with leaching time and temperature (Figs. 23, 24, 25). But when the temperature is low (25 and $45{ }^{\circ} \mathrm{C}$ ) the concentration of elements increase at maximum time of leaching of $8 \mathrm{~h}$ (Figs. 23, 24, 25). The release of $\mathrm{Pb}$ is maximum at $45^{\circ} \mathrm{C}$ which is independent of leaching (Fig. 25). The release of $\mathrm{Cu}, \mathrm{Co}$ and $\mathrm{Zn}$ from the coal and overburden is temperature as well as the leaching time dependent (Figs. 25, 26, 27, 28) Leaching rates of these elements increases gradually with time and temperature as indicated by Tables S25, S26, S27 and S28 (in supplementary information). The leaching of $\mathrm{Al}$ is fully leaching temperature dependent (Figs. 25, 26, 27, 28). From the Figs. 29 and 30 it is found that at high temperature most of the elements present in coal are leached when the leaching time is $1 \mathrm{~h}$ (Figs. 31, 32, 33, 34). The temperature dependence leaching of elements at a constant leaching time is shown in Tables S29 and S30 (see in supplementary information). In the case of $\mathrm{Fe}$, the concentration is higher in leachates than in raw samples (the maximum $\mathrm{Fe}$

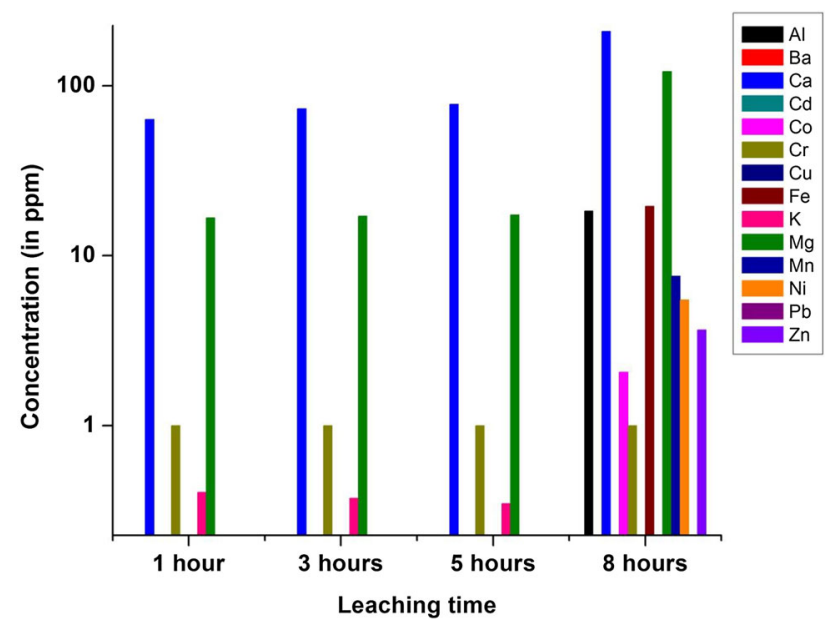

Fig. 24 Change in elemental concentration (in ppm) in aqueous leachates of Ledo coal (LC-60A) with leaching time (in hour) at $25{ }^{\circ} \mathrm{C}$

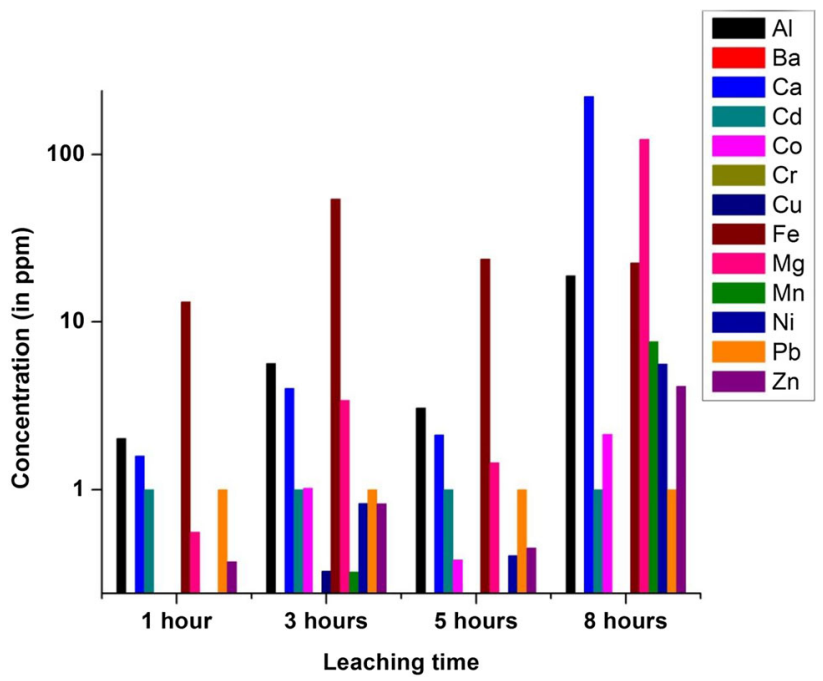

Fig. 25 Change in elemental concentration (in ppm) in aqueous leachates of Ledo coal (LC-20A) with leaching time (in hour) at $45^{\circ} \mathrm{C}$

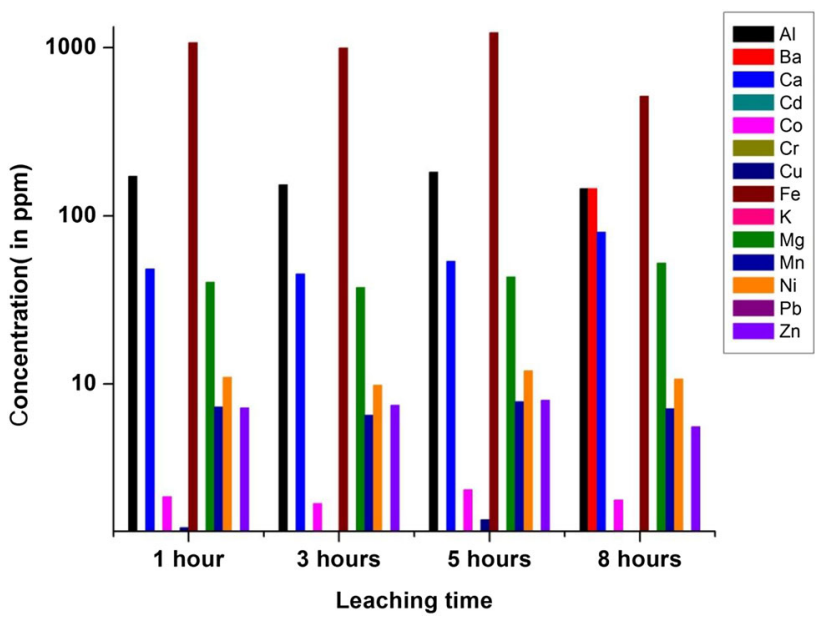

Fig. 26 Change in elemental concentration (in ppm) in aqueous leachates of Ledo coal (LC-60A) with leaching time (in hour) at $45^{\circ} \mathrm{C}$

concentration in raw coal was 43.1 and $2320 \mathrm{ppm}$ in the leachates of the coal samples).

\subsubsection{Field-emission-scanning-electron microscopic analysis}

In the FE-SEM analysis of raw coal samples of the Ledo coal (Fig. 35) it was found that barite $\left(\mathrm{BaSO}_{4}\right)$ and galena $(\mathrm{PbS})$ were associated with pyrite $\left(\mathrm{FeS}_{2}\right)$ which is not shown by EDS analysis of leached coal (Fig. 36). From the FE-SEM/EDS analysis of both the raw and leached samples, it was found that the atomic percentage of $\mathrm{Fe}$ in raw coal and overburden sample (LC-20A, LOB-15A) were $18.33 \%$ and $8.43 \%$ whereas in leached coal it was $7.84 \%$ 


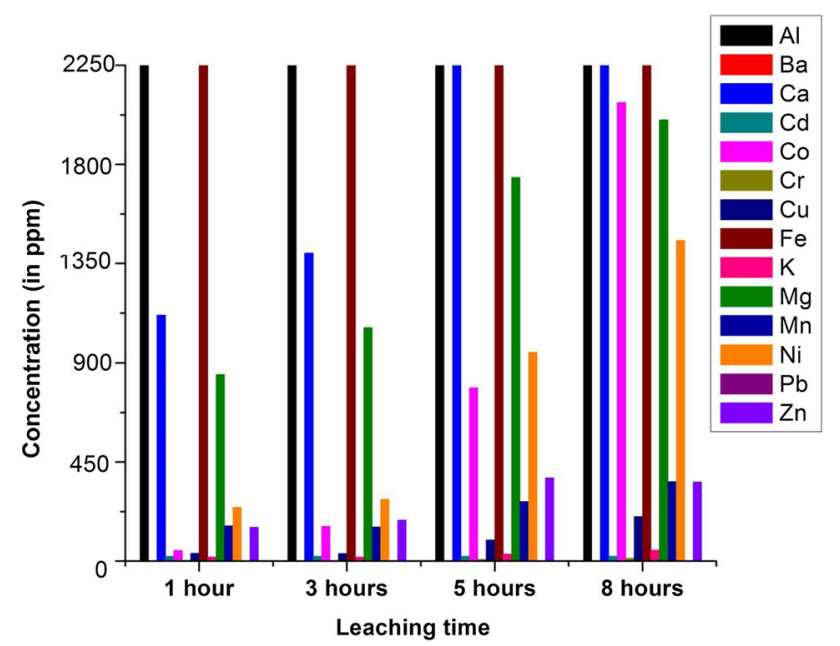

Fig. 27 Change in elemental concentration (in ppm) in aqueous leachates of Ledo coal (LC-20A) with leaching time (in hour) at $65{ }^{\circ} \mathrm{C}$

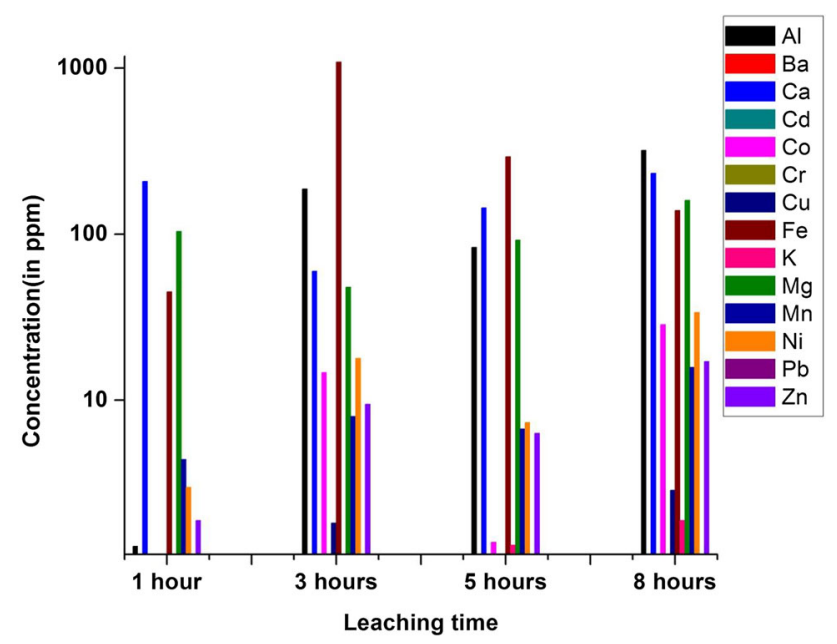

Fig. 28 Change in elemental concentration (in ppm) in aqueous leachates of Ledo coal (LC-60A) with leaching time (in hour) at $65{ }^{\circ} \mathrm{C}$

and $4.80 \%$ respectively. The FESEM-EDS analysis of leached coal and OB of the Ledo coal mine were carried out to find the approximate concentration of metals in the residues of leached samples.

\section{Discussions}

\subsection{Physico-chemical characteristics of aqueous leachates}

From the Table 1 it is found that the leaching at $45^{\circ} \mathrm{C}$ for $1,3,5$ and $8 \mathrm{~h}$ respectively demonstrate a gradual increase in $\mathrm{pH}$ values The gradual increase in $\mathrm{pH}$ (decrease in acidity) values implies that the continuous rainfall at

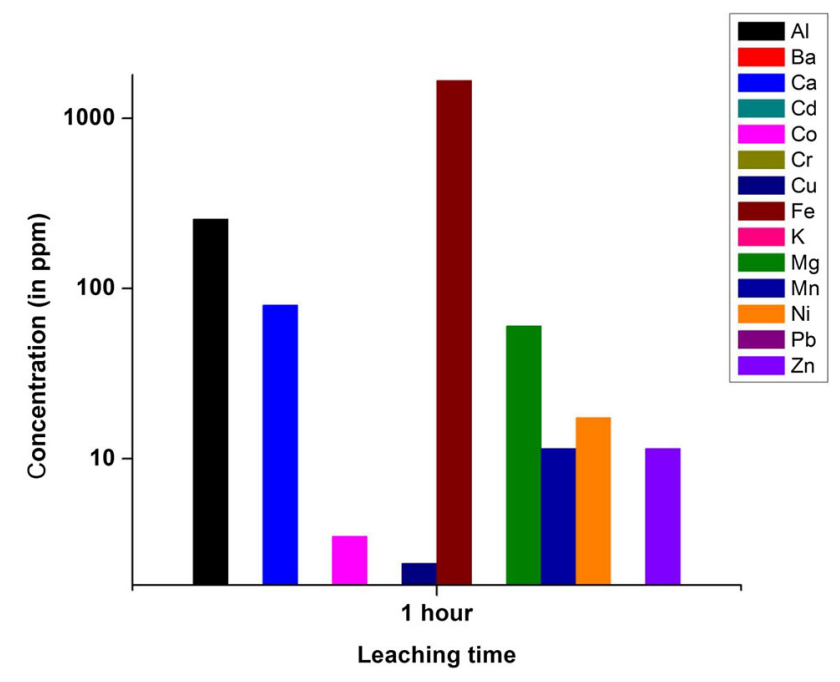

Fig. 29 Change in elemental concentration (in ppm) in aqueous leachates of Ledo coal (LC-20A) leaching for $1 \mathrm{~h}$ at $90{ }^{\circ} \mathrm{C}$

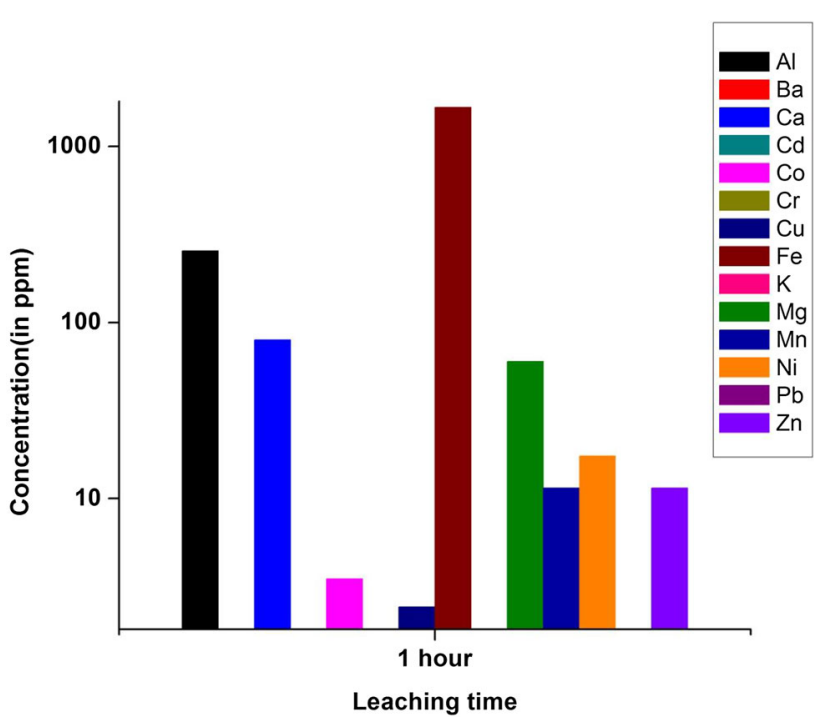

Fig. 30 Change in elemental concentration (in ppm) in aqueous leachates of Ledo coal (LC-60A) leaching for $1 \mathrm{~h}$ at $90{ }^{\circ} \mathrm{C}$

normal temperature for $5 \mathrm{~h}$ can generate AMD at the coal mine site. Thus, AMD from coal and mine OB are highly acidic at the coalfield site during the rainy season. The gradual increase in $\mathrm{pH}$ values of leachates at $45^{\circ} \mathrm{C}$ from 1 to $5 \mathrm{~h}$ indicates the low acidity of leachates with rise in leaching temperature. A high $\mathrm{pH}$ value of leachates may be attributed to the formation of $\mathrm{Ca}(\mathrm{OH})_{2}$ from $\mathrm{CaCO}_{3}$ present in overburden due to long time leaching (up to $8 \mathrm{~h}$ ), since the $\mathrm{pH}$ of a solution is an important determinant for counting aquatic toxicity. The amount of toxicity tends to be higher at low $\mathrm{pH}$ or high $\mathrm{pH}$ situations than at an approximately neutral $\mathrm{pH}$ (near $\mathrm{pH} 7$ ), since the dissolution of many metals can be considered as amphoteric, with a high tendency to dissolve and can form cations at low $\mathrm{pH}$ 


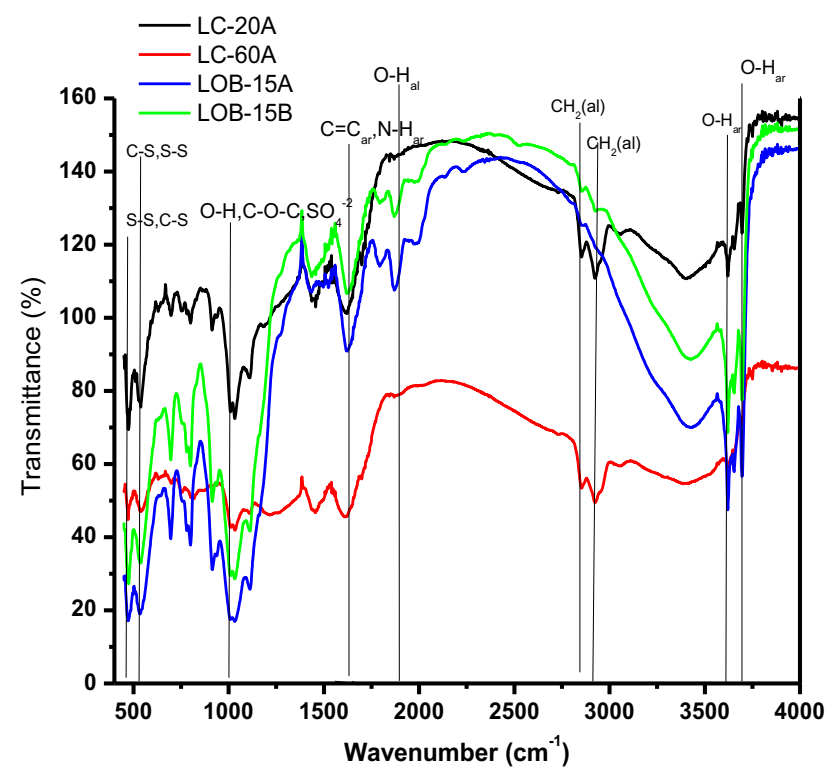

Fig. 31 FT-IR spectra for the leached coal and OB of the Ledo colliery

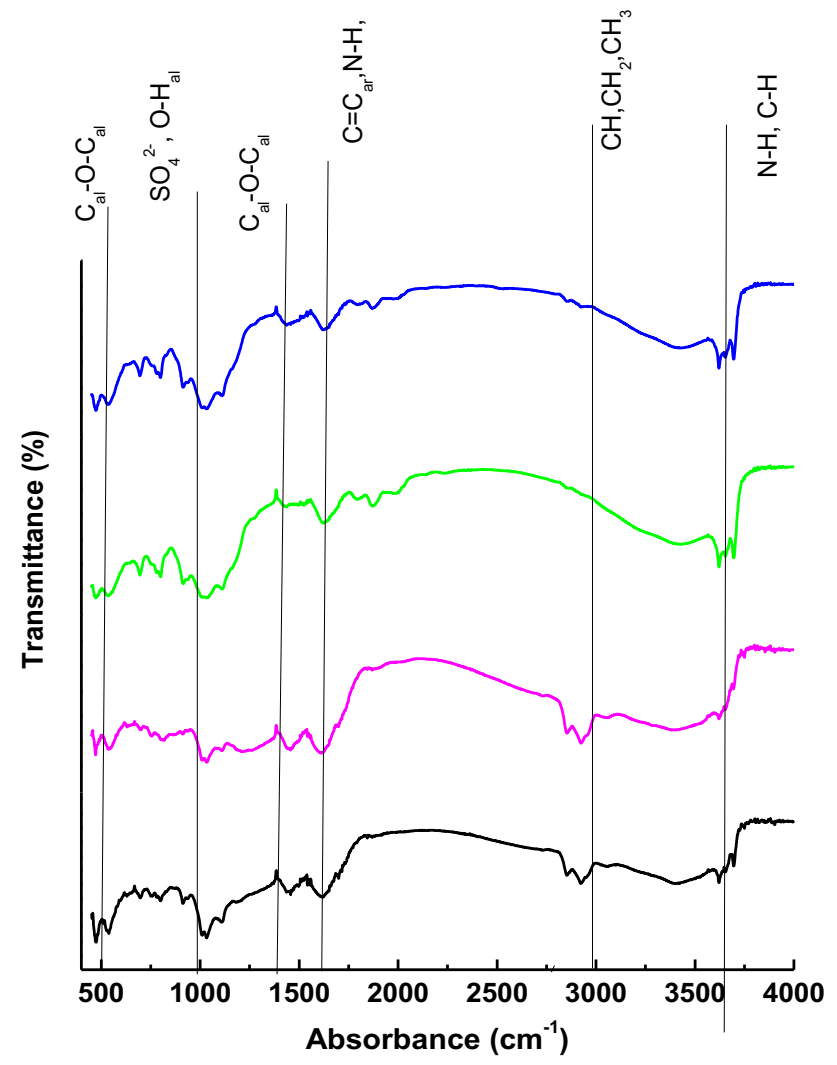

Fig. 32 FT-IR spectra for raw coal and OB of Ledo colliery

or anions at high $\mathrm{pH}$ values (Langmuir 1997). For instance, $\mathrm{Al}(\mathrm{OH})_{3}$ and different aluminosilicate minerals like kaolinite $\left[\mathrm{Al}_{2} \mathrm{Si}_{2} \mathrm{O}_{5}(\mathrm{OH})_{4}\right]$ have their minimum solubility at $\mathrm{pH}$ values 6-7 (Nordstrom and Ball 1986; Bigham and

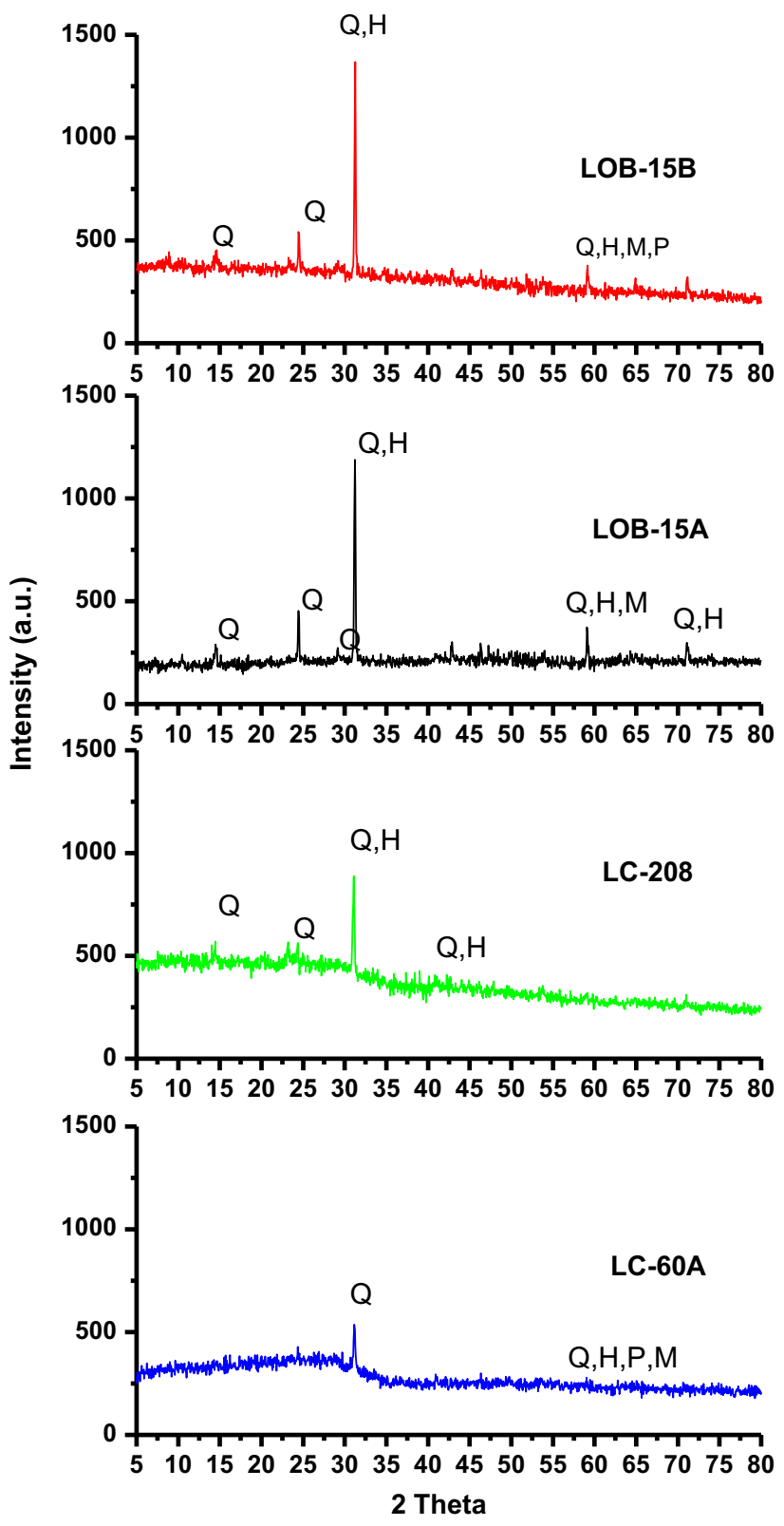

Fig. 33 XRD pattern of leached coal and OB of Ledo colliery

Nordstrom 2000) and even relatively low concentrations of dissolved $\mathrm{Al}$ can exert toxic effect to fish and other aquatic organisms (Baker and Schofield 1982; Elder 1998). The Environmental Protection Agency (EPA 2000, 2002a, b) recommends a $\mathrm{pH}$ 6.5-9.0 for protection of freshwater aquatic life and $\mathrm{pH} 6.5-8.5$ for public drinking purposes. In the present study the maximum $\mathrm{pH}$ values for leachates of overburdens were found to have a $\mathrm{pH}$ 9.4. This indicates a lower contamination of water resources from overburden than for coal. It should however be noted that $\mathrm{pH}$ is not the only determining factor of metals dissolution. Comparing the physical parameters of aqueous leachates of coal and overburden with the mine waste water it was found that the 
elements from coal and overburden can leach easily under normal weathering processes.

Again, from the Table 1, it was revealed that at room temperature the value of EC and TDS of leachates increase with leaching time. The high value of EC and TDS at a

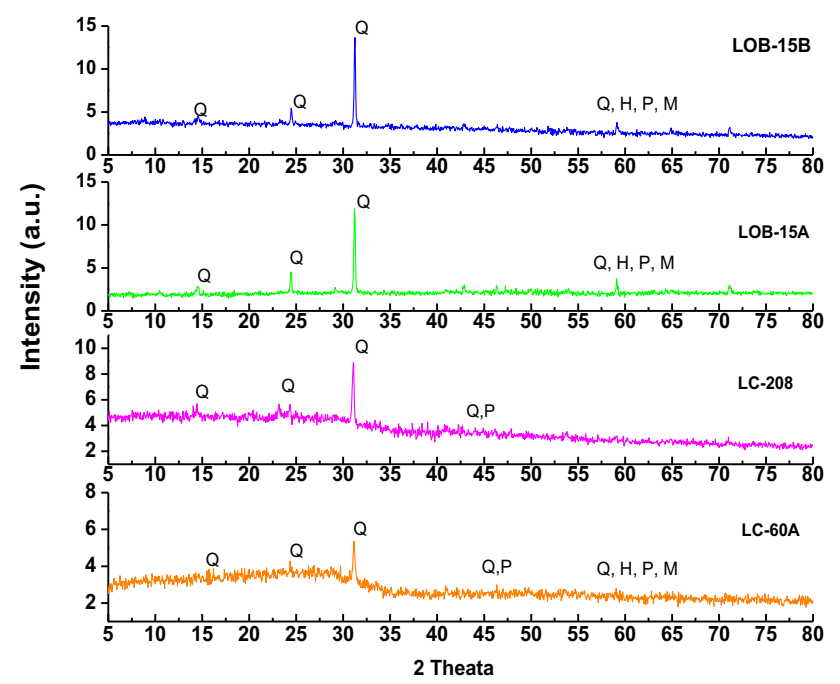

Fig. 34 XRD graph for raw coal and OB of Ledo colliery
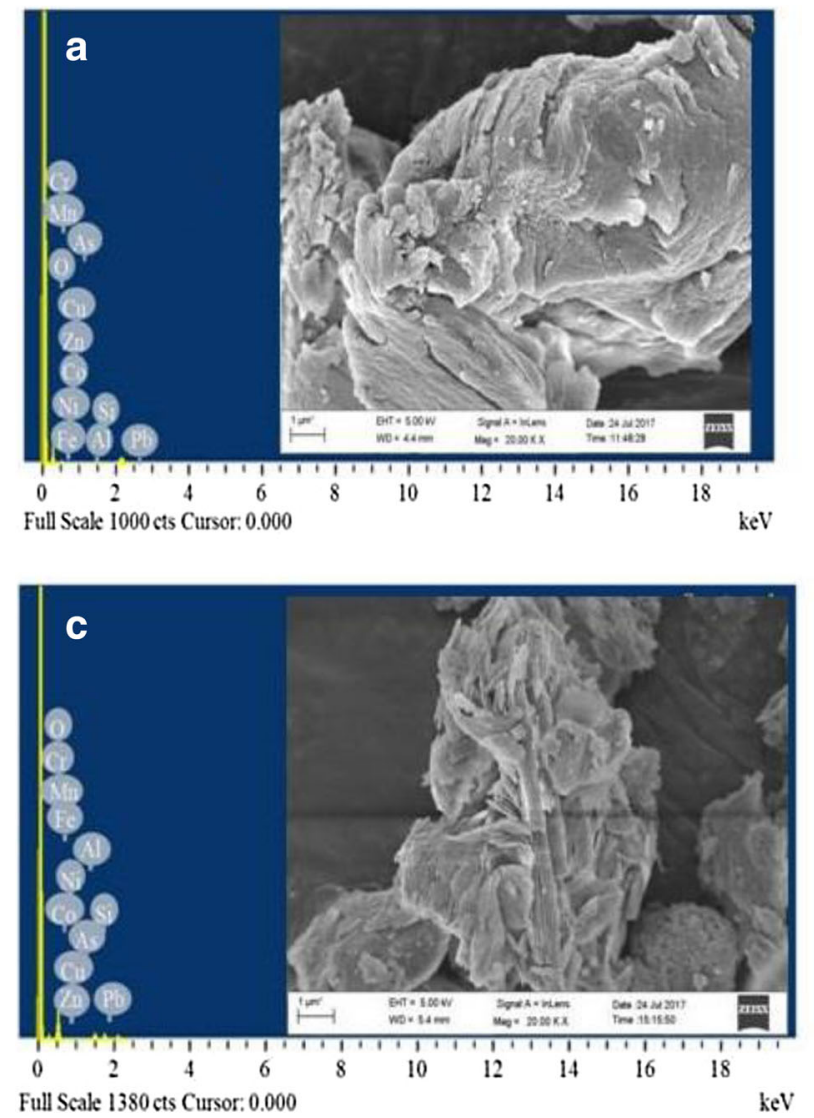

temperature higher than room temperature indicates the high mobility of ions present in the samples which were leached out of the sample as a result of leaching.

\subsection{Elemental characteristics of aqueous leachates}

\subsubsection{Ions present in the aqueous leachates of coals and overburdens}

Figures 9 and 10 show that the leaching of $\mathrm{Ca}^{2+}$ ion from Ledo coal is maximum at high temperature $65{ }^{\circ} \mathrm{C}$ which is an indication of maximum leaching of $\mathrm{Ca}^{2+}$ ion in monsoon season. The low concentration of $\mathrm{Na}^{+}, \mathrm{Mg}^{2+}, \mathrm{NH}_{4}^{+}$ and $\mathrm{Li}^{+}$ions in the leachates of coal and overburden at high temperature indicates minimum leaching of these ions in monsoon season. Table S5 shows the decrease in leaching of $\mathrm{Li}^{+}$ion with leaching duration. Since lithium is generally associated in coal and overburden as lithium silicate and the decrease in concentration of $\mathrm{Li}^{+}$ion in leachates with leaching time is attributed to the production of orthosilicic acid ( $\mathrm{Li}$ et al. 2017). Figures 11, 12, 13 and 14 show an increase in $\mathrm{F}^{-}, \mathrm{Cl}^{-}$and $\mathrm{SO}_{4}{ }^{2-}$ ion concentrations in aqueous leachates of Ledo coal and $\mathrm{OB}$ with leaching time which is due to the fact that leaching time is
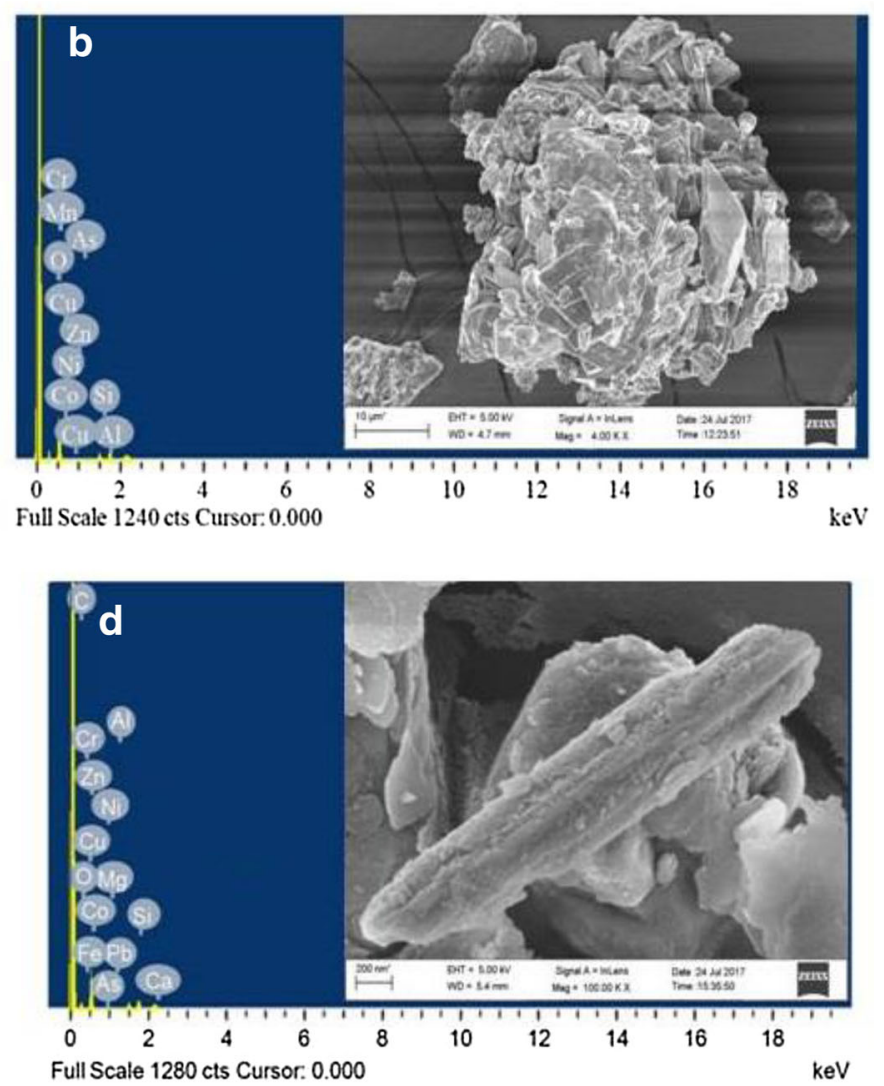

Fig. 35 FESEM-EDS micrographs of raw coal samples LC-20A (a), LC-60A (b) and OB samples LOB-15A (c), LOB-15B (d) 

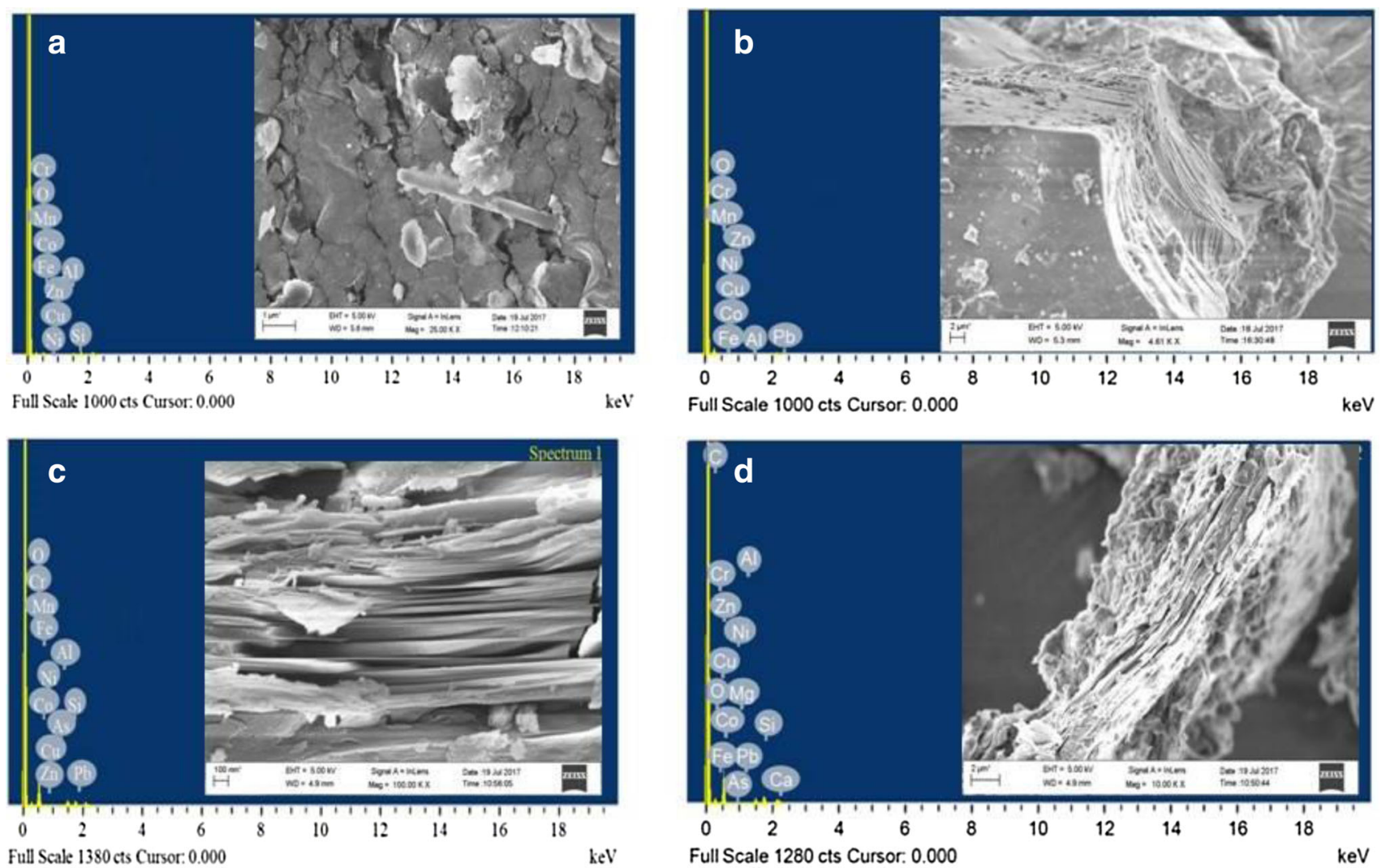

Fig. 36 SEM-EDS of leached coal LC-20A (e), LC-60A (f) and OB samples LOB-15A (g), LOB-15B (h)

an important factor which determine the amount of elements leached from the raw coal (Moyo et al. 2011). The leaching of $\mathrm{SO}_{4}{ }^{2-}$ ion from coal and overburden was increased with leaching temperature from 25 to $65^{\circ} \mathrm{C}$ and time (in Figs. 15, 16, 17, 18, 19, 20, 21, 22) which reveals the dependence of leaching of sulfate ion on leaching temperature and time.

\subsubsection{Major, minor and trace/hazardous elemental analysis}

Figures 23 and 24 show that the concentrations of major elements like Al. Fe, etc., minor element $\mathrm{Mn}$ and trace/hazardous elements like $\mathrm{Al}, \mathrm{Ba}, \mathrm{Co}, \mathrm{Ni}, \mathrm{Fe}, \mathrm{Mn}, \mathrm{Cu}$, $\mathrm{Zn}$, etc. increased with leaching time at room temperature $\left(25^{\circ} \mathrm{C}\right)$. But after $5 \mathrm{~h}$ of leaching the concentration of these elements gradually decreased which implies that at $25{ }^{\circ} \mathrm{C}$ most of the elements are released from the coal due to continuous raining of up to $5 \mathrm{~h}$. The release of $\mathrm{Pb}$ is maximum at $45^{\circ} \mathrm{C}$ which is independent of leaching (Fig. 25). This implies the mining temperature (ranges from 25 to $55{ }^{\circ} \mathrm{C}$ ) is favorable for release of $\mathrm{Pb}$ from coal as well as from overburden. The release of $\mathrm{Cu}$, $\mathrm{Co}$ and $\mathrm{Zn}$ from the coal and overburden is temperature as well as the leaching time dependent (Figs. 25, 26, 27, 28) which can be interpreted from the ICP-OES results of the mine water collected in different season and the leachates of coal and overburden at different temperatures. From the Figs. 29 and 30 it can be concluded that at high temperature most of elements are leached from coal even at a short leaching time. Since the concentration of $\mathrm{Fe}$ is more in aqueous leachates than in raw samples. This indicates that the maximum amount of $\mathrm{Fe}$ associated in coal can be leached with rain water due to continuous raining. In the present work the leaching experiment has been carried out to compare the leaching type of different elements with the natural processes like weathering. The process was associated with continuous stirring of the water mixture of the samples for increasing time interval $(1,3,5$ and $8 \mathrm{~h})$ at temperatures $25,45,65$ and $90{ }^{\circ} \mathrm{C}$.

\subsubsection{Field-emission-scanning-electron microscopic (FE- SEM) analysis}

Although association of barite and galena with pyrite was revealed by FE-SEM analysis (Fig. 35), but the EDS analysis of the leached coal sample (Fig. 36) has not shown any indication of the presence of both $\mathrm{Pb}$ and $\mathrm{Ba}$. The association of these sulfur minerals is responsible for highly acidic leachates due to weathering under natural 
condition. $\mathrm{Ba}$ and $\mathrm{Pb}$ present in coal can easily be released from coal at a lower pH (Giere and Stille 2004). Under the natural weathering condition, the coal associated with $\mathrm{Pb}$ and $\mathrm{Ba}$ undergoes leaching to release them and dissolve in AMD water, which was also confirmed by ICP-OES analysis of aqueous leachates of the Ledo coal at various time intervals. From the FE-SEM/EDS analysis of raw and leached samples (LC-20A, LOB-15A), it was found that the atomic percentage of $\mathrm{Fe}$ is different in both samples (raw and leached). It is happened because during the leaching process, the coal samples lost their structural behavior due to increased porosity owing to release of inorganic minerals from their surface (Manoj et al. 2009). From the FE-SEM/EDS analysis it was found that in Ledo coals, (LC-20A and LC-60A) the concentration of $\mathrm{Cd}, \mathrm{Cr}$ and $\mathrm{Ba}$ were found in very low concentrations which resembles with the ICP-OES analysis of aqueous leachates of coal. On the other hand, both analyses reported the excess concentrations of the elements $\mathrm{Ni}, \mathrm{Co}, \mathrm{Zn}, \mathrm{Cu}, \mathrm{Fe}$ (more than regulatory level). The FE-SEM/EDS elemental data of leached samples also can be co-related with the ICP-OES analytical data of aqueous leachates. The aqueous leachates of coal and $\mathrm{OB}$ at different leaching times and temperatures revealed maximum concentrations of $\mathrm{Fe}$ $(1670 \mathrm{ppm}), \quad \mathrm{Cr} \quad(0.62 \mathrm{ppm}), \quad \mathrm{Cd} \quad(0.002 \mathrm{ppm}), \quad \mathrm{Co}$ (92.5 ppm), $\mathrm{Ni} \quad(64.7 \mathrm{ppm}), \quad \mathrm{Pb} \quad(0.181 \mathrm{ppm}), \quad \mathrm{Ba}$ (0.213 ppm), Cu (9.02 ppm), and Zn (17.1 ppm) in ICPOES analysis. A high concentration of these elements in the leachates indicates their transfer from coal and OB under different chemical processes to the aqueous medium. It is to be noted that the intensity of the peaks found in the EDS graph of a sample cannot give a quantitative measure of elemental concentration; however, the EDS analysis could be used for qualitative identification of elements in the respective sample (Kutchko and Kim 2006). The composition of the elements is expressed in atomic and weight percentage (wt\%) and the detection limit of EDS is about $0.1 \mathrm{wt} \%$ (Kursula 2000).

\section{Mineralogy and functional groups in leached coals}

From the XRD analyses, it is reported that the minerals leached from coal and overburden (Fig. 33) are absent after leaching. In raw samples of coal (Fig. 34) the minerals quartz and hematite (d-values 3.3404 and 1.5789 respectively) were present, but in leached samples hematite was not found. The minerals quartz, hematite, pyrite, marcasite (d-values 3.3404, 1.5789, 1.8252 respectively) were found in the overburden $(\mathrm{OB})$ samples of both collieries. On the contrary to this, the leached samples of the overburden contain only quartz. This may be an indication of leaching of different minerals which are associated with different elements that can be leached in natural processes, like weathering. These minerals are mainly associated with $\mathrm{Fe}$. The absence of these minerals in the leached samples of coal and overburden indicates the easy leaching with rain water to form acid mine drainage (AMD).

FTIR analysis of raw and leached coal and overburden of Ledo colliery (see Figs. 31, 32) revealed the absence of some of the leached components from the samples of coal and overburden. The absorption bands for $\mathrm{CH}, \mathrm{CH}_{2}, \mathrm{CH}_{3}$ (al) are absent in the leached $\mathrm{OB}$ and the bands for both $\mathrm{OH}_{\mathrm{ar}},-\mathrm{OH}_{\mathrm{al}}$ are absent in both coal and OB. Although the absorption bands for $\mathrm{C}_{\mathrm{al}}-\mathrm{O}-\mathrm{C}_{\mathrm{al}}, \mathrm{SO}_{4}{ }^{2-}$ etc. are present in both raw and leached samples of coal and $\mathrm{OB}$ but the intensity of these peaks in the FTIR spectra of the leached samples are weak. This is due to the leaching of these samples which causes a low carbon and sulfur contents in the leached samples.

The major minerals present in coal are quartz, kaolinite, illite, calcite, carbonate, dolomite and sulfide mineral like pyrite (Ward 2002). From the XRD and FTIR analyses it was revealed that quartz, kaolinite and pyrite are the major minerals in the Ledo coal. Other Indian coals like Bokaro coal samples contain mostly kaolinite and quartz, but other minerals such as siderite and analcine are found as intermediate phases. In Neyeveli coal, dolomite and kaolinite are the major constituents with trace amounts of hematite and bassanite (Equeenuddin 2015). From analytical data it was found that the aqueous leachates of the Ledo coal are highly acidic ( $\mathrm{pH}$ range 1.99-3.09). But the leachates of other Indian coals have the normal $\mathrm{pH}$ range $(6.8-7.4)$ (Equeenuddin 2015). The strong acidic nature of the leachates of Ledo coal is due to the leaching of pyrite which is present in high amounts in the Ledo coal. The high concentration of iron $(1670 \mathrm{ppm})$ in the leachates is attributed to maximum leaching of pyrite. Low $\mathrm{pH}$ of aqueous leachates of Ledo coal leads to leach out most of the heavy metal from the coal.

\section{Comparison of aqueous leachates with coal mine water characteristic}

The aqueous leachates generated from coal and $\mathrm{OB}$ are compared with the AMD water collected from the coal mine. The parameters ( $\mathrm{pH}, \mathrm{EC}, \mathrm{TDS})$ are found to be similar as given in the Tables 1 and 2 respectively. The increase of $\mathrm{pH}$ values in mine water samples in comparison with aqueous leachates may be due to dilution during raining as well as ground water contamination. The comparable data reveals the simulation experiment of AMD on a large scale. 
Table 2 Geochemical analysis of mine water samples

\begin{tabular}{lllll}
\hline Sample type & Distance from AMD source $(\mathrm{km})$ & $\mathrm{pH}$ & EC $(\mu \mathrm{s} / \mathrm{cm})$ & TDS $(\mathrm{ppm})$ \\
\hline LW-15A & Sample point & 4.0 & 1226 & 927 \\
LW-15B & $0.5 \mathrm{~km}$ from sample point & 4.1 & 1234 & 915 \\
LW-15C & $0.5 \mathrm{~km}$ from sample point & 3.50 & 2290 & 1140 \\
LW-15D & $1 \mathrm{~km}$ from sample point & 3.30 & 2490 & 1180 \\
LW-15E (Ledopani river) & $2 \mathrm{~km}$ from sample point & 4.4 & 936 & 0.0468 \\
LW-15F (Kachanala stream) & $5 \mathrm{~km}$ from sample point & 5.0 & 659 & 0.0328 \\
\hline
\end{tabular}

\section{Conclusions}

Leaching is found to be one of the primary pathways for trace elements entering into the ecosystem. Dumping of coal and overburden causes large environmental degradation due to direct release of potentially hazardous elements through leaching and oxidation of pyrite minerals. The leaching property of different elements has been found to be dependent to several factors like specific element solubility and availability or release potential. Also the other factors that enhance the metal leaching include swiftly weathering metal containing minerals and the mine drainage conditions that can increase the solubility and flow rates through the contaminated mineral. The potential to produce acidity of drainage from mine water and mine wastes can be predicted by both geochemical methods static and kinetic leaching processes. The leachates generated from overburden dump are found to be rich in heavy metals specially $\mathrm{Fe}, \mathrm{Cu}, \mathrm{Mn}$ and Ni. The concentration of some of these elements increases with increase in leaching time and temperature. High concentration of elements in AMD water and other mine affected water resources is attributed to the continuous raining. Thus Ledo coal mine can cause more threat to the quality of water resources, ground as well as the surface water.

Some measures can be taken to minimize the natural leaching including re-mining, reclamation, and vegetation. These steps can reduce acid loads by covering acid producing materials, decreasing infiltration rates, removing the residual coal which at large area is the source of most of the pyrite. Vegetation can alter the soil cover systems by way of holes through roots and can uptake and transport contaminants present below the soil cover. Also, vegetation growth may increase the organic matter of the soil cover, and the decay of the plants consumes oxygen thereby decreasing the oxygen availability.

Acknowledgements Authors are thankful to Director, CSIR-NEIST (Jorhat) for his keen interest to this work. The funding from CSIR, New Delhi (OLP-2003) is duly acknowledged. Special thanks go to Prof. Frans Wandeers for editing the draft.

Open Access This article is distributed under the terms of the Creative Commons Attribution 4.0 International License (http:// creativecommons.org/licenses/by/4.0/), which permits unrestricted use, distribution, and reproduction in any medium, provided you give appropriate credit to the original author(s) and the source, provide a link to the Creative Commons license, and indicate if changes were made.

\section{References}

Alper B, Gulbin G, Fatma S, Ozgur O (2008) Effect of leaching temperature and $\mathrm{pH}$ on leachability of metals from fly ash. A case study: can Thermal power plant, Province of Canakkale, Turkey. Environ Monit Assess 139:287-298

Baker JP, Schofield CL (1982) Aluminum toxicity to fish in acid waters. Water Air Soil Pollut 18:289-309

Banerjee D (2014) Acid drainage potential from coal mine wastes: environmental assessment through static and kinetic tests. Int $\mathbf{J}$ Environ Sci Technol 11:1365-1378

Baruah MK, Gogoi PC (1998) A new form of sulphur in coal: the discovery of an iron-sulphur coordination compound. Fuel 77:979

Baruah BP, Saikia BK, Gogoi P, Kotoky P (2004) Acid mine drainage in Indian coal industry. International seminar on mineral processing technology

Baruah BP, Saikia BK, Kotoky P, Rao PG (2006) Aqueous leaching of high sulfur sub-bituminous coals in Assam, India. Energy Fuels 20:1550-1555

Bigham JM, Nordstrom DK (2000) Iron and aluminum hydroxysulfate minerals from acid sulfate waters. In: Jambor JL, Alpers CN, Nordstrom DK (eds) Sulfate minerals, crystallography, geochemistry and environmental significance, mineralogical society of America reviews in mineralogy and geochemistry, vol 40, pp 351-403

Chabukdhara M, Singh OP (2016) Coal mining in northeastern India: an overview of environmental issues and treatment approaches. Int J Coal Sci Technol 3:87-96

Chen J, Liu G, Kang Y, Wu B, Sun R, Zhou C, Wu D (2013) Atmospheric emissions of $\mathrm{F}, \mathrm{As}, \mathrm{Se}, \mathrm{Hg}$, and $\mathrm{Sb}$ from coal-fired power and heat generation in China. Chemosphere 90:1925-1932

Dai S, Ren D, Tang Y, Yue M, Hao L (2005) Concentration and distribution of elements in late Permian coals from western Guizhou Province, China. Int J Coal Geol 61:119-137

Dowarah J, DekaBoruah HP, GogoiJ Pathak N, Saikia N, Handique AK (2009) Eco-restoration of a high-sulfur coal mine overburden dumping site in northeastern India: a case study. J Earth Syst Sci 118:579-608

Dutta M, Saikia J, Taffarel SR, Waanders FB, Medeiros D, Cutruneo CMNL, Silva LFO, Saikia BK (2017) Environmental assessment and nano-mineralogical characterization of coal, overburden, 
and sediment from Indian coal mining acid drainage. Geosci Front 8:1285-1297

Elder JF (1998) Metal biogeochemistry in surface-water systems-a review of principles and concepts. US Geol Surv Circ 1013:32

EPA (2000) United States Environmental Protection Agency: methodology for deriving ambient water quality criteria for protection of human health.EPA/822/B-00/004, October 2000

EPA (2002a) US Environmental Protection Agency: guidance on choosing a sampling design for environmental data collection (QA/G-5S). EPA/240/R-02/005, December 2002

EPA (2002b) US Environmental Protection Agency: guidance on environmental data verification and data validation (QA/G-8). EPA/240/R-02/004, Office of the Environmental Information, Washington, DC

Equeenuddin SK SKMd (2015) Leaching of trace elements from Indian coal. J Geol Soc India 86:102-106

Ferguson KD, Erickson PM (1998) Pre-mine prediction of acid mine drainage. In: Environmental management of solid waste-dredge material and mine tailings. Springer, New York, pp 24-43

Finkelman RB (1994) Methods of occurrence of potentially hazardous elements in coal: levels of confidence. Fuel Process Technol 39:1817-1829

Fotoupoulou M, Siavalas G, Inaner H, Katsanou K, Lambrakis N, Christainis K (2010) Combustion and leaching behaviour of trace elements in lignite and combustion by-products from the Mugla basin, SW Turkey. In: Proceedings of the 12th international congress bulletin of the geological society of Greece

Giere R, Stille P (2004) Energy, waste, and the environment: a geochemical perspective. Geological Society, London, Special Publications, vol 236

Hesbach P, Beck M, Eick M, Lee DW, Burgers C, Greiner A (2005) Inter laboratory comparison of leaching methods. World Coal Ash (WOCA), Lexington

Johnson DW (1987) In situ toxicity tests of fishes in acid waters. Biogeochemistry 3(1-3):181-208

Kaeser AJ, Sharpe WE (2001) The influence of acidic runoff episodes on slimy sculp in reproduction in stone run. Trans Am Fish Soc 130(6):1106-1115

Kalembkiewicz J, Sitarz-Palczak E (2015) Efficiency of leaching tests in the context of the influence of the fly ash on the environment. J Ecol Eng 16(1):67-80

Kim AG, Kazonich G, Dahlberg M (2003) Solubility of cations in class F fly ash. Environ Sci Technol 37:4507-4511

Kimmel WG (1983) The impact of acid mine drainage on the steam ecosystem, Resources, Technology and Utilization, Pennsylvania, Pennsylvania Coal

Kursula PK (2000) Accuracy, precision and detection limits of SEMWDS, SEM-EDS and PIXE in the multi-elemental analysis of medieval glass. X-Ray Spectrom 29:111-118

Kutchko BG, Kim AG (2006) Fly ash characterization by SEM-EDS. Fuel 85:2537-2544

Langmuir D (1997) Aqueous environmental geochemistry. Colorado School of Mines. Prentice Hall, Upper Saddle River

Li S, Qin S, Kang L, Liu J, Wang J, Li Y (2017) An efficient approach for lithium and aluminum recovery from coal fly ash by predesilication and intensified acid leaching processes. Metals 7(7):272

Manoj B, Kunjomana AG, Chandrasekharan KA (2009) Chemical leaching of low-rank coal and its characterization using SEM/ EDAX and FTIR. J Miner Mater Charact Eng 8(10):821

Monterroso C, Macias F (1998) Drainage waters affected by pyrite oxidation in a coal mine in Galicia (NW Spain): composition and mineral stabilities. Sci Total Environ 126:121-132

Moyo S, Mujuru M, McCrindle RI, Matlala NM (2011) Environmental implications of material leached from coal. J Environ Monit 12:3047-3310
Mukherjee S, Borthakur PC (2003) Effect of leaching high sulfur subbituminous coal by potassium hydroxide and acid on removal of mineral matter and sulfur. Fuel 82:783-788

Nordstrom DK, Ball JW (1986) The geochemical behavior of aluminum of acidified surface. Science 232:40-41

Prachiti PK, Manikyamba C, Singh PK, Balaram V, Lakshminarayana G, Raju K, Singh MP, Kalpana MS, Arora M (2011) Geochemical systematics and precious metal content of the sedimentary horizons of lower Gondwanas from the Sattupalli coal field, Godavari Valley, India. Int J Coal Geol 88:83-100

Querol X, Izquierdo M, Monfort E, Alvarez E, Font O, Moreno T, Alastuey A, Zhuang X, Lu W, Wang Y (2008) Environmental characterization of burnt coal gangue banks at Yangquan, Shanxi Province, China. Int J Coal Geol 75:93-104

Schippers A, Jozsa PG, Sand W (1996) Sulfur chemistry in bacterial leaching of pyrite. Appl Environ Microbiol 62:3424-3431

Singh MP, Singh PK (1995) Mineral matter in the Rajmahal coals: study through incident light microscopy and scanning electron micrography. J Geol Soc India 46:557-564

Singh PK, Singh AL, Kumar A, Singh MP (2012a) Mixed bacterial consortium as an emerging tool to remove hazardous trace metals from coal. Fuel 102:227-230

Singh PK, Singh MP, Singh AK, Naik AS (2012b) Petrographic and geochemical characterization of coals from Tiru valley, Nagaland, NE India. Energy Explor Exploit 30(2):171-192

Singh AK, Singh MP, Singh PK (2013) Petrological investigations of oligocene coals from foreland basin of northeast India. Energy Explor Exploit 31(6):909-936

Singh AL, Singh PK, Singh MP, Kumar A (2015a) Environmentally sensitive major and trace elements in Indonesian coal and their geochemical significance energy sources part a: recovery, utilization, and environmental effects, vol 37. Taylor \& Francis, New York, pp 1836-1845

Singh PK, Rajak PK, Singh MP, Naik AS, Singh VK, Raju SV, Ojha $S$ (2015b) Environmental geochemistry of selected elements in lignite from Barsingsar and Gurha Mines of Rajasthan, Western India. J Geol Soc India 86:23-32

Singh PK, Rajak PK, Singh MP, Singh VK, Naik AS (2016) Geochemistry of Kasnau-Matasukh lignites, Nagaur basin, Rajasthan (India). Int J Coal Sci Technol 3(2):104-122

Swain DJ, Goodarzi F (1995) Environmental aspects of trace elements in coal. Kluwer, Norwell, pp 111-127

Swaine DJ (2000) Why trace elements are important. Fuel Process Technol 65-66:21-23

Swine DJ (1990) Trace elements in coal. Butterworths, London, p 294

Tiwari RK (2001) Environmental impact of coal mines on water regime and its management. Int $\mathrm{J}$ Water Air Soil Pollut 132(1-2):185-199

Tomeczec J, Palugniok H (2002) Kinetics of mineral matter transformation during coal combustion. Fuel 81:1251-1258

US DOE (2005) International energy outlook. US DOE, Washington

Wang Y, Ren D, Zhao F (1999) Comparative leaching experiments for trace elements in raw coal, laboratory ash, fly ash and bottom ash. Int J Coal Geol 40:103-108

Ward CR (2002) Analysis, and significance of the mineral matter in coal mines. Int J Coal Geol 50:135-168

Yang L, Bai JSX, Song B, Wang R, Zhou T, Jia J, Pu H (2016) Leaching behavior and potential environmental effects of trace elements in coal gangue of an open-cast coal mine area, inner Mongolia. China Miner 6(2):50

Zhou C, Liu G, Wu D, Fang T, Wang R, Fan X (2014) Mobility behavior and environmental implications of trace elements associated with coal gangue: a case study at the Huainan Coalfield in China. Chemosphere 95:193-199 